\title{
LES PRINCIPALS NOVETATS INTRODUÏDES PER LA DIRECTIVA 2008/98/CE SOBRE RESIDUS I LES LÍNIES D’ACTUACIÓ EN LA SEVA TRANSPOSICIÓ A L'ORDENAMENT ESPANYOL ${ }^{()}$
}

\author{
Noemi BlÁzQuez Alonso \\ Professora associada de Dret Administratiu \\ Universitat Internacional de Catalunya \\ Advocada \\ Despatx Uría Menéndez \\ nba@uria.com
}

Rebut: 1 d'abril de 2010 / Acceptat: 20 de maig de 2010

RESUM: El proper 12 de desembre de 2010 finalitza el termini per a què els Estats membres transposin la Directiva marc de residus. Malgrat que la Directiva ha estat titllada per representants europeus i organitzacions ecologistes com a norma "massa feble", el cert és que la norma comunitària pretén introduir nous conceptes clau en el marc de la producció i gestió de residus i revisar els ja existents en vista de l'abundant jurisprudència dictada pel Tribunal de Justícia de la Unió Europea.

Aquest estudi analitza les novetats que aporten la nova Directiva marc i els primers treballs realitzats pel Ministeri de Medi Ambient i Medi Rural i Marí en la transposició de la norma comunitària a l'ordenament espanyol, així com la possible aplicació directa de la Directiva marc en cas de manca de transposició o transposició incorrecta.

Això sense perjudici de que seran els governs autonòmics els que, en l'exercici de les competències que tenen atribuïdes en matèria de medi ambient, dissenyin les polítiques aplicables al tractament i gestió dels seus residus. No obstant això, caldria aprofitar

\footnotetext{
(.) L'autora agraeix al Prof. Dr. Juan Antonio Pérez Rivarés les seves aportacions a aquest treball. Qualsevol error o imprecisió és d'exclusiva responsabilitat de l'autora.
} 
l'oportunitat que ofereix la transposició de la Directiva Marc per harmonitzar els diferents règims autonòmics.

RESUMEN: El próximo 12 de diciembre de 2010 finaliza el plazo para que los Estados miembros transpongan la Directiva marco de residuos. A pesar de que la Directiva ha sido tildada por representantes europeos y organizaciones ecologistas como norma "demasiado débil", lo cierto es que la norma comunitaria pretende introducir nuevos conceptos clave en el marco de la producción y gestión de residuos y revisar los ya existentes a la vista de la abundante jurisprudencia dictada por el Tribunal de Justicia de la Unión Europea.

El presente estudio aborda las novedades que aportan la nueva Directiva marco y los primeros trabajos realizados por el Ministerio de Medio Ambiente y Medio Rural y Marino en la transposición de la norma comunitaria al ordenamiento español, así como la posible aplicación directa de la Directiva marco en caso de falta de transposición o transposición incorrecta.

Ello sin perjuicio de que serán los gobiernos autonómicos los que, en el ejercicio de las competencias que tienen atribuidas en materia de medio ambiente, diseñen las políticas aplicables al tratamiento y gestión de sus residuos. Debería, no obstante, aprovecharse la oportunidad que brinda la transposición de la Directiva Marco para armonizar los distintos regímenes autonómicos.

ABSTRACT: The deadline to transpose Directive 2008/98/EC into Spanish law is December 12 2010. Although this Directive has been branded by European representatives and environmental organizations as being "too weak", it seeks to introduce new waste production and management concepts. It also reviews the existing concepts in view of the extensive case law issued by the European Court of Justice.

This study focuses on the novelties of Directive 2008/98/EC and the implementation works carried out by the Spanish Ministry of Environment and Rural and Marine Affairs, and its possible direct application in the event that the Directive is incorrectly or not implemented at all. 
In Spain, the regional governments are in charge of designing the environmental policies applicable to waste treatment and management. This Directive gives rise to the opportunity to harmonize the different regional regulations on waste treatment.

PARAULES CLAU: Efecte directe — Subproducte — Residu — Valorització

PALABRAS CLAVE: Efecto directo - Subproducto — Residuo - Valorización

KEYWORDS: Direct effect — By-product — Waste — Recovery

Sumari: I. Introducció. II. Regulació de residus a Espanya. 1. Antecedents normatius. 2. La normativa vigent: Llei 10/1998, de 21 d'abril, de residus. 2.1. Àmbit d'aplicació. 2.2. Classificació dels residus. 2.3. Sobre les obligacions del productor de residus. 2.4. Sobre les obligacions del gestor de residus. 2.5. Trasllat dels residus. 2.6. Planificació dels residus. 2.7. Sòls contaminats. 2.8. Reforma de la Llei 10/1998 per la Llei Òmnibus. III. Principals novetats introduïdes per la Directiva Marc. 1. Àmbit d'aplicació. 2. El concepte de residu. 2.1. Residu. A. Interpretació no restrictiva del concepte de residu. B. Interpretació conjunta i teleològica del concepte de residu. C. Irrellevància de la possible reutilització econòmica de la substància o objecte en qüestió. D. Irrellevància del tractament que pugui donar-se a la substància 0 objecte en qüestió. E. Intencionalitat. F. Opinió de la societat. 2.2. Biorresidu. 2.3. Subproducte. 2.4. Fi de la condició de residu. 3. Responsabilitat ampliada del productor. 4. Jerarquia de residus. 5. Valorització. 6. Autoritzacions. IV. Avenços en la transposició de la Directiva Marc. 1. Residus urbans. 1.1. Concepte de residu urbà i la seva gestió. 1.2. Recollida separada de residus per al seu adequat reciclat. 2. Biorresidus. 3. Règim regulador. 3.1. Autoritzacions, comunicacions i llibre registre. 3.2. Fi de la condició de residu i subproducte. 4. Residus perillosos. 5. Responsabilitat ampliada del productor. V. La invocabilitat i l'eficàcia directa de la Directiva Marc. 1. Règim jurídic de les Directives comunitàries. 2. Invocabilitat $\mathrm{i}$ efecte directe vertical de la Directiva Marc: supòsit de reconeixement de drets als particulars. 3. Efecte directe vertical "d'exclusió" de la Directiva Marc: paràmetre d'aplicació de les normes nacionals. 4. Efecte directe vertical de la Directiva Marc en "relacions triangulars". VI. Conclusions. VII. Bibliografia consultada.

\section{INTRODUCCIÓ}

E1 22 de novembre de 2008 es va publicar en el Diari Oficial de la Unió Europea la Directiva 2008/98/CE sobre Residus, coneguda com la Directiva Marc de Residus (la “Directiva Marc"). L'article 40 de la Directiva emplaça els Estats membres a transposar la norma abans del 12 de desembre de 2010.

A aquest efecte, i a falta de que es publiqui l'avantprojecte pel qual es transposi la Directiva Marc, el Ministeri de Medi ambient i Mitjà Rural i Marí (el "Ministeri”) va elaborar el passat 19 de gener de 2010 una presentació amb motiu de la reunió del Grup de Treball de Residus del Consell Assessor de Medi Ambient en el qual s'avançava quin hauria de ser el sentit de la norma de transposició. 
La transposició de la Directiva Marc suposa una oportunitat per a l'actualització i unificació de la normativa sobre residus. A més, la Directiva Marc deroga tres directives anteriors (la Directiva 75/439/CEE de 16 de juny, relativa als olis usats, la Directiva 91/689/CEE, de 12 de desembre, relativa a los residus perillosos i la Directiva 2006/12/CE de 5 d'abril, relativa als residus). Per això, és possible que, de manera similar, canviï significativament el panorama legislatiu espanyol que afecta a la gestió de residus.

En el context descrit, aquest article té per objecte l'estudi de les principals novetats introduïdes per la Directiva Marc, així com les línies d'actuació que està duent a terme el Grup de Treball de Residus del Consell Assessor de Medi Ambient a l'efecte de transposar la Directiva.

En aquest sentit, s'exposarà succintament la legislació estatal de residus existent en l'actualitat, així com la valoració i justificació dels principals canvis previstos en la nova Directiva Marc. Identificades les modificacions, s'assenyalaran els avenços en la transposició de la norma comunitària a l'ordenament espanyol, així com l'eficàcia directa de la Directiva Marc en cas de manca de transposició o transposició incorrecta.

\section{REGULACIÓ DE RESIDUS EN ESPANYA}

\section{Antecedents normatius}

Fins a 1998, la legislació estatal aplicable als residus estava constituïda principalment per la Llei 42/1975, de 19 de novembre, sobre deixalles i residus sòlids urbans (la "Llei 42/1975") ${ }^{1}$ i per la Llei 20/1986, de 14 de maig, bàsica de residus tòxics i perillosos (la “Llei 20/1986”). No obstant això, com a conseqüència de l'adhesió d'Espanya a la Comunitat Econòmica Europea es va transposar la Directiva 75/442/CE del Consell, del 15 de juliol de 1975, relativa als residus (la "Directiva 75/442/CE"), mitjançant el Reial Decret Legislatiu 1163/1986, de 13 de juny que va modificar la Llei 42/1975.

\footnotetext{
${ }^{1}$ La Llei 42/1975 incloïa entre els residus urbans aquells que fossin conseqüència de les activitats domiciliàries, comercials $\mathrm{i}$ de serveis; però també les activitats sanitàries $\mathrm{i}$ de neteja viària, $\mathrm{i}$ els residus derivats de l'abandó d'animals morts, mobles, estris i vehicles. En relació amb els residus industrials, només quedaven inclosos els residus produïts en les indústries agrícoles, i s'exceptuaven les deixalles de les activitats agrícoles i ramaderes en llur fase d'explotació quan es produïssin i dipositessin en sòl qualificat com no urbanitzable.
} 
Per la seva banda, la Llei 20/1986 va ser desenvolupada pel Reial Decret 833/1988, de 20 de juliol i pel Reial Decret 952/1997, que modificava l'anterior.

La transposició de la Directiva 75/442/CE va exigir adaptar la Llei 42/1975 a l'ordenament comunitari, introduint per primera vegada una sèrie de definicions, com és el concepte residu ${ }^{2}$ o de gestió, tractament, eliminació i aprofitament de residus ${ }^{3}$, que, a partir d'aquest moment, resultaran clau per a la correcta aplicació del règim jurídic als agents que intervenen en la producció i gestió dels residus.

D'acord amb la Llei 42/1975, els productors i posseïdors de residus sòlids urbans estaven obligats a posar aquests residus a disposició de l'Ajuntament, el qual n'adquiria la propietat des de llur lliurament i recollida. No obstant això, hi havia la possibilitat de que els propis productors o posseïdors dels residus procedissin al seu tractament, prèvia obtenció de la llicència municipal adient ${ }^{4}$.

En relació a l'aprofitament de recursos, la legislació espanyola vigent en aquell moment estava pensant en empreses particulars per a la realització d'aquestes operacions, com demostra el fet de que en cap moment s'al-ludís a iniciatives municipals. Les instal-lacions també havien de ser autoritzades tant per l'Ajuntament com pel Ministeri d'Indústria. L'impuls de les operacions d'aprofitament podia realitzar-se instant-se als titulars de les installacions a la seva ampliació o modificació amb vista a un aprofitament més racional, concedint-se a aquests efectes ajudes econòmiques i podentse procedir a l'expropiació de la instal-lació si no es realitzaven les ampliacions proposades. L'atorgament de l'autorització d'aprofitament duia implícita la declaració

\footnotetext{
${ }^{2}$ Es defineix com residu: "Qualsevol substància o objecte del que es desprengui el seu posseïdor o tingui l'obligació de desprendre's en virtut de les disposicions en vigor” (art. 1.2 de la Llei 42/1975).

${ }^{3}$ Es defineix com gestió: "El conjunt d'activitats encaminades a donar a aquests la destinació més adequada i d'acord amb les seves característiques, per a la protecció de la salut humana, els recursos naturals i el medi ambient. Comprèn: a) Les operacions de recollida, emmagatzematge, transport, tractament i eliminació. b) Les operacions de transformació necessàries per a la seva reutilització, la seva recuperació o el seu reciclatge."

Es defineix com tractament: "El conjunt d'operacions encaminades a l'eliminació de les deixalles i residus o a l'aprofitament dels recursos continguts en ells."

Es defineix com eliminació de residus: "Tots aquells procediments dirigits, bé a l'emmagatzematge o abocament controlat dels residus o bé a la seva destrucció, total o parcial, per incineració o altre sistema que no impliqui recuperació d'energia".

Es defineix com aprofitament: "Tot procés industrial l'objecte del qual sigui la recuperació o transformació dels recursos continguts en els residus." (art. 1.2 de la Llei 42/1975). ${ }^{4}$ Pel que fa als residus sòlids industrials, els Ajuntaments podien imposar a llurs productors l'obligació de
constituir dipòsits o abocadors propis o procedir a la seva eliminació.
} 
d'utilitat pública d'aquestes activitats i l'accés dels seus titulars als beneficis que concedeix la Llei de 16 de desembre de 1954, d'expropiació forçosa ${ }^{5}$.

Aquest marc normatiu va canviar amb la promulgació de la Llei 10/1998, de 21 d'abril de residus (la "Llei 10/1998"), la necessitat de la qual era doblement sentida.

D'una banda, l'ampli ventall normatiu regulador dels residus requeria una norma de capçalera. Els supòsits de fet relatius a la producció i a la gestió dels residus van donar lloc a un enorme i complexíssim bloc normatiu, sent més que necessària la presència d'una norma directriu que li donés coherència, inspirant-lo i informant-lo de manera que fora en ella on poguessin buscar-se els principis generals que donessin unitat al grup normatiu.

D’altra banda, la modificació pràcticament íntegra de la Directiva 75/442/CEE per la Directiva 91/156/CEE del Consell de 18 de març obligava a dictar una llei general de residus. La transposició es va fer cinc anys després de que expirés el termini concedit per a la seva transposició, i un cop condemnada Espanya pel retard en la transposició ${ }^{6}$.

\section{La normativa vigent: Llei 10/1998, de 21 d'abril, de residus}

\section{1. Àmbit d'aplicació}

La Llei 10/1998 té per objecte prevenir la producció de residus, establir el règim jurídic de llur producció i gestió, i fomentar, per aquest ordre, llur reducció, reutilització, reciclat $\mathrm{i}$ altres formes de valorització.

S'aplica a tot tipus de residus, excepció feta de les emissions a l'atmosfera, dels residus radioactius i dels abocaments d'afluents líquids a les aigües ${ }^{7}$.

\footnotetext{
${ }^{5}$ Sobre aquest particular, vid. MARTÍN MATEO, R., Tratado de Derecho Ambiental, Trivium, Madrid, 1992, p. 540ss.

${ }^{6}$ Sentència del TJCE de 5 de juny de 1997, Comissió c/ Espanya, as. C-107/96, Rep. 1997, p. I-3193.

${ }^{7}$ Tanmateix, la Llei 10/1998 s'aplica supletòriament en aquells aspectes regulats per la seva normativa específica, a la gestió dels residus resultants de les activitats mineres, a l'eliminació i transformació de desaprofitaments d'origen animal, als residus agraris quan s'utilitzin en el marc de les explotacions agràries, als explosius, cartutxeria $\mathrm{i}$ artificis pirotècnics desclassificats, $\mathrm{i}$ a les terres separades en les indústries agroalimentàries en les seves fases de recepció i de neteja primària de les matèries primeres agrícoles, quan estiguin destinades a una millora ecològica dels sòls i l'agricultura. La previsió d'un règim especial per a aquest tipus de residus troba la seva raó d'ésser en l'existència de normativa sectorial pròpia.
} 


\subsection{Classificació dels residus}

La Llei 10/1998 acull la definició de residu prevista en la Llei 42/1975, això és, “qualsevol substància o objecte [...] del que el seu posseïdor es desprengui o del que tingui intenció o l'obligació de desprendre's" i afegeix “pertanyent a alguna de les categories que figuren en l'Annex d'aquesta Llei"8. El legislador estatal precisa que, en tot cas, tindran aquesta consideració els que figurin en el Catàleg Europeu de Residus (CER) aprovat per les Institucions Comunitàries.

Aquest concepte, sobre el qual tornarem quan tractem la Directiva Marc, ha estat llargament debatut per la jurisprudència i la doctrina, especialment pel que fa al significat del terme "desprendre's".

Dins el concepte genèric de residu, la Llei 10/1998 distingeix entre residus urbans ${ }^{9} \mathrm{i}$ residus perillosos ${ }^{10}$.

La doble classificació dels residus es tradueix en una dualitat de règims. Així, la Llei 10/1998 estableix unes normes generals per als residus i, addicionalment, unes regles especials per al tractament dels residus urbans o perillosos, de les quals ens ocuparem en els apartats següents.

\footnotetext{
${ }^{8}$ L'Annex de la Llei 10/1998 divideix els residus en setze categories, entre les quals destaquen la classificació dels productes que no responguin a les normes o que estiguin caducats o la utilització de les quals estigui prohibida per la Llei.

${ }^{9}$ Són residus urbans o municipals els que són resultat del consum ordinari en els domicilis particulars o comerços, oficines i serveis, així com tots aquells que no tinguin la qualificació de perillosos i que per llur naturalesa o composició puguin assimilar-se als produïts en aquells llocs o activitats. A més, la Llei 10/1998, en línia amb allò disposat en l'anterior Llei 42/1975, identifica expressament com a residus urbans els residus procedents de la neteja de vies públiques, zones verdes, àrees recreatives i platges, els animals domèstics morts, així com mobles, estris i vehicles abandonats i els residus i enderrocs procedents d'obres menors de construcció i reparació domiciliària.

${ }^{10}$ Es consideren residus perillosos aquells que figuren a la llista de residus perillosos aprovada en el Reial Decret 952/1997, de 20 de juny, pel qual es modifica el Reglament per a l'execució de la Llei 20/1986, aprovat mitjançant el Reial Decret 833/1988, de 20 de juliol; així com els recipients i envasos que els hagin contingut, els quals hagin estat qualificats com a tal per la normativa comunitària, i els quals pugui aprovar el Govern de conformitat amb allò establert per la normativa europea o en els convenis internacionals. Sens dubte, la Llei 10/1998 proporciona una definició de residu perillós prou àmplia, quan no indeterminada, com per donar cabuda a totes aquelles substàncies que puguin suposar un perill per al medi ambient i la salut de les persones.
} 


\subsection{Sobre les obligacions del productor de residus}

Sobre la base de la definició de productor, la Llei 10/1998, en el seu article 7, imposa una sèrie d'obligacions al productor de residus, entès aquest no només com aquella persona física o jurídica l'activitat de la qual (exclosa la derivada del consum domèstic) produeixi els residus, sinó també com l'importador o adquirent intracomunitari, agent o intermediari, o qualsevol altra persona responsable de l'entrada en el mercat de productes que amb llur ús esdevinguin residus ${ }^{11}$.

Aquests subjectes estaran obligats a (a) elaborar productes que per llur característiques afavoreixin la prevenció en la generació de residus, o permetin llur eliminació en la forma menys perjudicial per a la salut i el medi ambient; (b) fer-se càrrec de la gestió dels residus derivats dels seus productes, o alternativament a (i) participar en un sistema organitzat de gestió o contribuir econòmicament als sistemes públics de gestió de residus o (ii) acceptar, de no aplicar-se el sistema de gestió, un sistema de dipòsit, devolució i retorn dels residus derivats dels seus productes; i (c) informar anualment als òrgans competents de les Comunitats Autònomes on radiquin les seves instal-lacions dels residus produïts en el procés de fabricació i del resultat qualitatiu i quantitatiu de les operacions efectuades.

Per la seva banda, els productors de residus perillosos estan obligats, addicionalment, a separar adequadament i no barrejar els residus perillosos evitant particularment aquelles barreges que suposin un augment de llur perillositat o dificultin llur gestió. Complementàriament, hauran d'envasar i etiquetar els recipients que continguin residus perillosos en la forma que reglamentàriament es determini, tot podent emmagatzemar llurs propis residus perillosos durant un període màxim de sis mesos.

\subsection{Sobre les obligacions del gestor de residus}

Juntament amb el productor, la Llei 10/1998 regula també la figura del gestor de residus. Aquesta figura ja venia contemplada en l'encara vigent Reial Decret 833/1988,

\footnotetext{
${ }^{11}$ A aquests efectes convé posar de manifest que la definició de "productor" de residus d'acord amb l'article 2 de la Llei 10/1998 no inclou "a l'agent o intermediari, o qualsevol altra persona responsable de la entrada en el mercat de productes que amb el seu ús es converteixin en residus". Es tracta, per tant, d'una ampliació dels subjectes responsables en matèria de producció de residus que té la seva lògica donat que suposa una extensió del règim de responsabilitat de tots els agents intervinents en la cadena de producció i venda de productes susceptibles de generar residus.
} 
de 20 de juliol, pel qual s'aprova el Reglament per a l'execució de la Llei 20/1986, bàsica de residus tòxics i perillosos.

D’acord amb la Llei 10/1998, gestor és la persona o entitat, pública o privada, que realitzi qualssevulla de les operacions que componen la gestió dels residus, sigui o no el productor dels residus, mentre que la gestió és la recollida, l'emmagatzematge, el transport, la valorització i l'eliminació dels residus, inclosa la vigilància d'aquestes activitats.

Les operacions de gestió dels residus han de dur-se a terme sense posar en perill la salut humana i sense utilitzar procediments ni mètodes que puguin perjudicar el medi ambient. És per això que la realització de les operacions de valorització i eliminació de residus s'ha de sotmetre a una prèvia autorització de l'òrgan medi ambiental competent de la Comunitat Autònoma per un temps determinat i renovable ${ }^{12}$.

No obstant això, les Comunitats Autònomes poden eximir de l'exigència d'autorització a les empreses i establiments que s'ocupin de la valorització o de l'eliminació dels seus propis residus no perillosos, sempre que es dictin normes en les quals es fixin els tipus i quantitats de residus i les condicions en que l'activitat pot quedar dispensada de l'autorització.

A més, aquesta autorització no serà exigible o aplicable a les activitats de gestió de residus urbans realitzades per entitats locals, tret que així ho estableixin les respectives Comunitats Autònomes ${ }^{13}$.

La fiscalització de l'activitat de gestió no es limita al control autoritzatori. Una vegada obtinguda la preceptiva autorització, el titular de l'activitat ha de dur un registre documental en el qual figurin la quantitat, naturalesa, origen, destinació, freqüència de

\footnotetext{
${ }^{12}$ L'autorització es concedeix per un període de cinc anys, susceptible de dues pròrrogues successives $i$ automàtiques d'altres cinc anys cadascuna, previ informe favorable després de la corresponent visita d'inspecció. Així mateix, les autoritzacions per a la gestió de residus tenen un termini de caducitat de quinze anys (art. 30 del Reial decret 833/1988, de 20 de juliol, pel qual s'aprova, el Reglament per a l'execució de la Llei 20/1986, bàsica de residus tòxics i perillosos). Sobre les principals característiques de l'autorització, vid. ORTEGA BERNARDO, J., La intervención pública en la gestión de los residuos industriales, Montecorvo, Madrid, 2002, p. 157ss.

${ }^{13}$ Ha de tenir-se present, no obstant això, que les activitats d'eliminació, mitjançant dipòsit en abocador, de residus urbans realitzades pels ens locals, estaran sotmeses a l'autorització ambiental integrada quan es tractin d'abocadors que rebin més de 10 tones de residus per dia o que tinguin una capacitat total de més de 25.000 tones (a exclusió dels abocadors de residus inerts), de conformitat amb la Llei 16/2002, de 1 de juliol, de prevenció i control integrats de la contaminació.
} 
recollida, mitjà de transport i mètode de revalorització o eliminació dels residus gestionats.

En relació amb la gestió dels residus perillosos, les particularitats de la Llei 10/1998 se centren en la necessària autorització per a llur recollida i emmagatzematge, així com per al seu transport. Les autoritzacions han de fixar un termini i queden subjectes a la constitució pel sol-licitant d'una assegurança de responsabilitat civil i a la prestació d'una fiança ${ }^{14}$.

\subsection{Trasllat dels residus}

Pel que fa al trasllat dels residus, la Llei 10/1998 s'inclina pel principi de proximitat, taxant els supòsits en els quals les Comunitats Autònomes poden oposar-se a la recepció de residus produïts en el territori nacional. L'entrada i sortida de residus en i des del territori nacional es regirà per la normativa comunitària i pels tractats internacionals dels quals Espanya sigui part.

Correspon a l'Administració General de l'Estat l'autorització dels trasllats de residus des de o cap a tercers països no membres de la Unió Europea i la inspecció derivada del citat règim de trasllats, essent igualment competent quan Espanya sigui Estat de trànsit ${ }^{15}$.

\subsection{Planificació dels residus}

La idea de la planificació, com instrument que ha d'ajudar a la prevenció, subjeu en tot el text de la Llei 10/1998. Correspon a l'Administració General de l'Estat elaborar els

\footnotetext{
${ }^{14}$ Sobre l'obligatorietat de l'assegurança de responsabilitat i de la fiança exigible als gestors de residus perillosos, ha de tenir-se present que els gestors estan habilitats per (i) substituir les esmentades assegurances o fiances per unes altres mitjançant les quals es cobreixin també les responsabilitats que derivin de la Llei 26/2007, de 23 d'octubre, o (ii) complementar-les amb aquesta mateixa finalitat (Disposició Addicional tercera del Reial Decret 2090/2008, de 22 de desembre, pel qual s'aprova el Reglament de desenvolupament parcial de la Llei 26/2007, de 23 d'octubre, de responsabilitat mediambiental).

${ }^{15}$ Així ho preveu l'article 4 de la 1lei 10/1998, en relació amb l'article 53 del Reglament 1013/2006 del Parlament Europeu i del Consell, de 14 de juny de 2006, relatiu al trasllat de residus.
} 
plans nacionals de residus ${ }^{16}$ i la integració dels respectius plans autonòmics de residus en ells.

En l'àmbit autonòmic, el Programa de Gestió de Residus Municipals de Catalunya (“PROGREMIC") constitueix el programa de planificació de la gestió de residus municipals, i estableix les línies estratègiques que es desenvoluparan durant els anys corresponents (en l'actualitat està vigent el PROGREMIC corresponent al període 2007 a 2012$)^{17}$.

Les principals novetats d'aquest programa consisteixen en tenir com a eix principal el desenvolupament dels instruments necessaris per aconseguir els objectius de prevenció i valorització a través de les persones, ja sigui de forma individual, com a activitat econòmica o com a entitat social (Eix d'actuació 1: Programa per a la ciutadania) ${ }^{18} \mathrm{o}$ formant part de les organitzacions relacionades amb la gestió (Eix d'actuació 2: Programa de Gestió) ${ }^{19}$.

Per la seva banda, Catalunya ha desenvolupat, en relació amb la gestió dels residus industrials, el Programa de Gestió de Residus Industrials ("PROGRIC") 20 .

${ }^{16}$ Els Plans nacionals són aprovats pel Consell de Ministres i revisats cada quatre anys, mentre que correspon a les Comunitats Autònomes l'elaboració dels plans autonòmics de residus i a les entitats locals, si escau, l'elaboració dels seus propis plans de gestió de residus.

${ }^{17}$ L'objectiu pretès és una major eficiència en l'ús dels recursos $i$ una gestió dels recursos i dels residus que assegurin models de producció i consum més sostenibles, dissociant l'ús dels recursos i la generació dels residus de la taxa de creixement econòmica.

Pel que fa als objectius quantitatius, es preveu una reducció de la generació de residus per càpita del 10\% respecte a l'any 2006. Per la seva banda, es preveu, en termes generals, que la valorització material total dels residus ascendeixi al $48 \%$, tot establint límits específics atenent al tipus de residu en concret (vidre, paper i cartró, matèria orgànica, etc.). Per últim, es preveu una disminució progressiva de residus sense tractar la incineració fins a arribar al 100\% de tractament en el 2012.

${ }^{18}$ En el primer eix s'atorga primacia a totes aquelles actuacions encaminades a permetre la participació de la ciutadania en la gestió, com per exemple, l'establiment de mesures de foment del consum responsable, mesures econòmiques per fomentar certes conductes o les actuacions de participació i educació ambiental bàsiques per a l'èxit del nou PROGREMIC.

19 L'eix segon del programa es centra en l'organització i logística, promovent canvis en l'estructura organitzativa vinculada a la gestió de residus, que permetin modificar la relació entre els diferents gestors i dins de les mateixes Administracions Públiques, tot millorant la cooperació entre ells, guanyant en eficiència i implicació i optimitzant els resultats finals del model de gestió, amb base en criteris de territorialitat $\mathrm{i}$ transversalitat. També inclou un programa d'infrastructures en el qual es descriuen les infrastructures necessàries per tractar els residus generats segons els objectius i escenaris planejats. A aquests efectes es tindrà en compte la quantitat i quantia dels residus a tractar, llur ubicació i l'adequació de la tecnologia escollida a aquest efecte.

20 Els objectius del nou programa (actualment vigent des de 2007 fins a 2012) són, entre d'altres, minimitzar la generació de residus industrials i reduir llur perillositat, potenciant l'adopció de les millors tècniques disponibles, augmentar quantitativament i qualitativament la valorització dels residus, potenciar 


\subsection{Sòls contaminats}

Cal fer especial esment a la previsió que contempla la Llei 10/1998 sobre els sòls contaminats. D'acord amb l'article 27 d'aquesta Llei, les Comunitats Autònomes havien de declarar, delimitar i fer un inventari dels sòls contaminats a causa de la presència de components de caràcter perillós d'origen humà i avaluar els riscos per a la salut humana o el medi ambient, d'acord amb els criteris i estàndards que es determinin, en funció de la naturalesa dels sòls i dels usos ${ }^{21}$.

No obstant això, la gran novetat estreba en que per primera vegada, el legislador estatal aborda la problemàtica sobre qui ha de respondre de les operacions de recuperació $\mathrm{i}$ neteja dels espais degradats ${ }^{22}$. D'aquesta manera, la declaració d'un sòl com a contaminat obliga a realitzar les actuacions necessàries per a procedir a la seva neteja $\mathrm{i}$ recuperació als causants de la contaminació, que quan siguin varis, respondran de forma solidària, i subsidiàriament, per aquest ordre, els posseïdors dels sòls contaminats i els propietaris no posseïdors.

És important posar èmfasi en la consideració legal dels posseïdors i propietaris dels sòls contaminats com a subjectes obligats a llur neteja i recuperació, ja que es tracta de persones que poden no haver tingut res a veure amb la contaminació mateixa. Per aquest motiu, es pot parlar, més que d'una simple responsabilitat objectiva (on el causant del dany n'és responsable, amb independència de la seva possible negligència), d'una responsabilitat absoluta, això és, de fer responsable algú fins i tot en el supòsit de que no se li pugui atribuir causalment el dany de cap manera ${ }^{23}$.

A més, el simple abandó del sòl contaminat no eximeix de les obligacions previstes en relació amb els sòls contaminats; a excepció del creditor, que en execució forçosa del

l'autosuficiència territorial, minimitzant les necessitats de transport, millorar la separació en origen dels residus assimilables a urbans, afavorir la participació i col-laboració de tots els agents implicats, etc. El PROGRIC estableix com a objectius quantitatius a assolir en 2012 que la valorització dels residus sigui del $80 \%$ i que la disposició del rebuig sigui del 19\%.

${ }^{21}$ En matèria de sòls contaminats, la Llei 10/1998 ha estat desenvolupada pel Reial Decret 9/2005, de 14 de gener, pel qual s'estableix la relació d'activitats potencialment contaminants del sòl, i els criteris i estàndards per a la declaració de sòls contaminats.

${ }^{22}$ No obstant això, convé tenir present que la derogada Llei catalana 6/1993, de 15 de juliol, reguladora dels residus ja contemplava en el seu article 15 els subjectes responsables en el cost de les operacions de neteja i recuperació dels terrenys contaminats i espais degradats.

${ }^{23}$ Referent a això, veure DE MIGUEL PERALES, C., Régimen jurídico español de suelos contaminados, Civitas, Pamplona, 2007, p. 108ss. 
seu crèdit, esdevé propietari d'un sòl contaminat, sempre que ho alieni en el termini d'un any a partir de la data en que va esdevenir propietari, sobre el qual no recaurà aquesta responsabilitat.

\subsection{Reforma de la Llei 10/1998 per la Llei Òmnibus}

La Llei 10/1998 ha estat objecte de diverses modificacions, essent la més recent la introduïda en el seu articulat per la Llei 25/2009, de 22 de desembre, de modificació de diverses lleis per a la seva adaptació a la Llei sobre el lliure accés a les activitats de serveis i llur exercici (la “Llei Òmnibus”).

Entre les novetats més significatives, la Llei Òmnibus introdueix un article 6 bis en la Llei 10/1998 pel qual es crea un registre estatal de producció i gestió de residus que serà únic per a tot el territori espanyol, i al que les diferents Comunitats Autònomes han d'incorporar la informació i autoritzacions que tinguin en matèria de residus. Així mateix, l'article 10 del mateix cos legal és modificat a fi d'exigir una comunicació prèvia a l'inici d'activitats de trasllat i canvi de possessió dels residus.

L'article 13, en el seu apartat primer, també ha estat desenvolupat i ampliat exigint la submissió a règim d'autorització, no només a les instal·lacions on es prevegi dur a terme activitats de valorització o eliminació de residus, sinó també, a les persones físiques o jurídiques que realitzin aquestes activitats, prèvia comprovació de que les instal·lacions disposin de l'autorització indicada o d'autorització ambiental integrada. No obstant això, en aquells casos en què les persones físiques o jurídiques que realitzin les operacions siguin també les titulars de les instal-lacions, es concedirà una sola autorització que comprengui tant la instal-lació com l'activitat exercida pel titular d'aquesta.

Finalment, la Llei 25/2009 modifica l'article 15 de la Llei 10/1998, tot establint l'obligació de les Comunitats Autònomes d'inscriure en un registre únic la informació que obtinguin en relació amb els titulars d'activitats en les quals es desenvolupin operacions de gestió de residus no perillosos diferents a la valorització o l'eliminació. No obstant això, s'ha suprimit l'habilitació que tenien les Comunitats Autònomes per sotmetre aquestes activitats a autorització. 


\section{PRINCIPALS NOVETATS INTRODUÏDES PER LA DIRECTIVA MARC}

\section{1. Àmbit d'aplicació}

De la mateixa manera que succeïa amb l'anterior normativa, la Directiva Marc estableix dos tipus d'exclusions en el seu àmbit d'aplicació: d'una banda, les exclusions totals, que en qualsevol cas queden al marge de la Directiva Marc; i, d'altra banda, les exclusions que es produeixen només en la mesura en que estiguin cobertes per una altra normativa $^{24}$.

Pel que fa a les exclusions, és digna de ressaltar l'exclusió realitzada per la Directiva Marc dels sediments reubicats en l'interior de les aigües superficials a l'efecte de gestió de les aigües i de les vies navegables de prevenció de les inundacions o de mitigació dels efectes de les inundacions o les sequeres o de recuperació de terres, si es demostra que aquests sediments no són perillosos.

A aquests efectes, hem d'entendre que si el sediment extret de les aigües superficials o vies navegables, malgrat tenir la consideració de substància contaminant, no suposa un perill per al medi ambient o la salut de les persones i se li pot assignar un ús productiu, reparatiu o preventiu (a títol d'exemple, quan s'utilitzi el material en la restauració de platges o la recuperació d'un pantà i les característiques de qualitat del material obtingut s'ajustin als requisits exigits per a tal fi), es tractaria d'un producte, evitant així la seva gestió com a residu.

24 Vid. SERRANO PAREDES, O., "La Nueva Directiva de Residuos: Principales Novedades", Ecosostenible, núm. 47, gener 2009, p. 4ss.

La Directiva Marc preveu com autèntiques novetats, respecte de la regulació comunitària, les següents exempcions: (a) el terra (in situ), inclòs el sòl no excavat contaminat i els edificis en contacte permanent amb la terra; (b) el sòl no contaminat i altre material en estat natural excavat durant les activitats de construcció quan es té la certesa que el material s'utilitzarà a l'efecte de construcció en el seu estat natural en el lloc del que es va extreure; (c) els residus radioactius i explosius desclassificats (que a diferència del que succeïa sota la Directiva 2006/12/CE de 5 d'abril, de residus, la seva exclusió deixa d'estar condicionada a que estiguin cobertes per una altra normativa específica i passen a estar-ho en tot cas); $i$ (d) les matèries fecals (tret que es tracti de subproducte animal), palla i altre material natural, agrícola o silvícola, no perillós, utilitzat en l'agricultura, en la silvicultura o en la producció d'energia a força d'aquesta biomassa, mitjançant procediments o mètodes que no facin malbé el medi ambient o posin en perill la salut humana. 


\section{El concepte de residu, biorresidu, subproducte i fi de la condició de residu}

\subsection{Residu}

La Directiva Marc adopta la definició prevista en el marc normatiu anterior:

“A efectos de la presente Directiva se entiende por:

1) «residuo»: cualquier sustancia u objeto del cual su poseedor se desprenda o tenga la intención o la obligación de desprenderse”.

No obstant això, a diferència de la Directiva 2006/12/CE de 5 d'abril, relativa als residus i la Llei 10/1998, la norma no exigeix la inclusió de la substància o objecte en un Annex.

Aquesta novetat té relació amb els pronunciaments del Tribunal de Justícia de les Comunitats Europees (el “TJCE”) ${ }^{25}$, en els quals s'ha indicat que el citat Annex precisa i il·lustra la definició, tot proposant una llista de substàncies i objectes de residus. És més, es tracta d'una llista purament indicativa. En aquest context, l'article 7.1 de la Directiva Marc fa esment a la Llista Europea de Residus i, de nou, en línia amb la jurisprudència comunitària, s'assenyala que la inclusió d'una substància o objecte en la llista no significarà que s'hagi de considerar residu en totes les circumstàncies, sinó únicament quan compleixi la definició de residu.

Per tant, el rellevant a l'efecte de determinar si una determinada substància té consideració de residu o no, depèn del comportament del posseïdor i del significat del terme "desprendre's", de conformitat amb els criteris utilitzats pel TJCE. I aquesta precisió té especial sentit des d'una perspectiva econòmica, donat que una mateixa substància podrà qualificar-se com residu o com subproducte, en funció de la intenció que tingui el posseïdor de desprendre's de la substància en qüestió.

Com a punt de partida, el TJCE ha assenyalat que el fet que una substància o objecte tingui la consideració jurídica de residu (i, per això, que en un moment donat pugui deixar de ser-ho) depèn de les circumstàncies específiques de cada cas concret. Segons

\footnotetext{
${ }^{25}$ Com a conseqüència de l'entrada en vigor del Tractat de Lisboa el passat 1 de desembre de 2009, l'antic TJCE ha esdevingut el "Tribunal de Justícia" (sense cognom) que, conjuntament amb el Tribunal General (substitut del Tribunal de Primera Instància), integra l'actualment denominat Tribunal de Justícia de la Unió Europea.
} 
el TJCE, és l'autoritat competent de cada Estat membre la que ha d'adoptar aquesta decisió, cas per cas, $\mathrm{i}$ atenent a les circumstàncies concretes d'aquest ${ }^{26}$.

És necessari, per tant, fer una anàlisi dels criteris establerts pel TJCE, en diferents supòsits concrets, per concloure si una determinada substància o objecte havia o no de considerar-se com a residu.

A continuació s'analitzen aquests criteris, que, com es veurà, no són determinants considerats de manera aïllada. Han de ser valorats conjuntament $i$ a la llum de les circumstàncies específiques del cas concret.

A més de la jurisprudència del TJCE, també cal tenir en compte la "Comunicació al Consell i al Parlament Europeu interpretativa sobre residus i subproductes" elaborada per la Comissió Europea en data 21 de febrer de 2007 (la “Comunicació de 21 de febrer de 2007 " $)^{27}$, que té per objecte "explicar la definició de residu que figura en l'article 1 de la Directiva [2006/12/CE i que reprodueix la Llei 10/1998], a la llum de la interpretació del TJCE, per garantir la correcta aplicació de la Directiva"28.

\section{A. Interpretació no restrictiva del concepte de residu}

El TJCE ha vingut manifestant en diverses sentències que el concepte de residu no pot ser objecte d'interpretació restrictiva ${ }^{29}$, si bé, segons assenyala la Comunicació de 21 de febrer de 2007, una interpretació excessivament àmplia de la definició de residu imposaria costos innecessaris a les empreses afectades i podria reduir l'atractiu de materials que, d'una altra manera, serien susceptibles de reutilització econòmica.

\footnotetext{
${ }^{26}$ Per totes, vegi's la Sentència del TJCE, d'1 de març de 2007, KVZ retec, as. C-176/05, Rep. 2007, p. I1721 (FJ 50 a 52).

${ }^{27}$ COM (2007) 59 final.

${ }^{28}$ La Comunicació de 21 de febrer de 2007 té un gran valor interpretatiu del concepte de residu, tota vegada que ha estat elaborada per la Comissió Europea tenint en compte els criteris jurisprudencials analitzats en l'apartat 3.2 d'aquest treball, amb la finalitat de marcar les pautes de la futura legislació comunitària en matèria de residus i subproductes. De fet, tal com exposa la introducció d'aquest document, "per millorar la seguretat jurídica de la legislació en matèria de residus i facilitar la comprensió i aplicació de la definició d'aquests darrers, la present Comunicació pretén, d'una banda, orientar a les autoritats competents al decidir cas per cas, si un material determinat és o no residu [...]. La Comunicació també ajudarà a harmonitzar la interpretació d'aquestes disposicions a la UE".

29 Sentències del TJCE de 15 de juny de 2000, ARCO Chemie Nederland $i$ altres, as. C-418/97 i C419/97, Rep. 2000, p.I-4475 (FJ 4) i de 18 d'abril de 2002, Palin Granit and Vehmassalon kansaterveystyön kuntayhtymän hallitus, as. C-9/00, Rep. 2002, p.I-3533 (FJ 23 i 36); i Interlocutòria del TJCE de 15 de gener de 2004, Saetti and Frediani, as. C-235/02, Rep. 2004, p.I-1005 (FJ 36).
} 
A la vista de l'exposat, pot concloure's que, sense perjudici de tenir en compte la necessitat de protegir el medi ambient i fer una aplicació deguda de les normes ambientals en general, i en particular, de les referides a residus, caldrà interpretar les normes de tal manera que es permeti la utilització de certs béns amb beneficis no només econòmics, sinó també ambientals. Una interpretació excessivament estricta del concepte de residu podria ser contrària a aquesta finalitat.

\section{B. Interpretació conjunta i teleològica del concepte de residu}

La caracterització jurídica d'una substància o objecte com a residu ha de verificar-se a la llum del conjunt de circumstàncies que envolten la seva generació i posterior ús o tractament, atenent al cas concret, tenint en compte l'objectiu de la normativa sobre residus i vetllant perquè no es minvi la seva eficàcia ${ }^{30}$.

Sobre aquest particular, el TJCE entén que una substància o objecte pot ser considerat com residu si la seva composició no és adequada per a la utilització que es fa d'ella o si ha d'utilitzar-se amb especials mesures de precaució en raó del perill que comporti la seva composició per al medi ambient ${ }^{31}$. En cas contrari, estem davant d'un indici de que aquesta substància o objecte no és un residu.

Així mateix, l'actual article 191.2 del Tractat de funcionament de la Unió Europea ${ }^{32}$ conté el principi de correcció, preferentment en la font mateixa, dels atemptats al medi ambient $^{33}$. Finalment, en nombroses ocasions el TJCE ha tingut ocasió de pronunciar-se sobre l'obligació dels Estats membres de prendre les mesures adequades per fomentar la prevenció o la reducció dels residus ${ }^{34}$.

\footnotetext{
${ }^{30}$ Comunicació de 21 de febrer de 2007, apartat 3.1, paràgraf segon.

${ }^{31}$ Sentències del TJCE de 15 de juny de 2000, ARCO Chemie Nederland $i$ altres, as. C-418/97 i C419/97, Rep. 2000, p.I-4475 (FJ 88); de 18 d'abril de 2002, Palin Granit and Vehmassalon kansaterveystyön kuntayhtymän hallitus, as. C-9/00, Rep. 2002, p.I-3533 (FJ 43); Interlocutòria del TJCE de 15 de gener de 200,4 Saetti and Frediani, as. C-235/02, Rep. 2004, p.I-1005 (FJ 39).

${ }^{32}$ Antic article 174.2 del Tractat constitutiu de la Comunitat Europea.

${ }^{33}$ Sentència del TJCE de 10 de maig de 1995, Comissió c/ Alemanya, as. C-422/92, Rep. 1995, p.I-1097 (FJ 28).

${ }^{34}$ Sentències del TJCE de 25 de juny de 1997, Tombesi, as. C-304/94, C-330/94, C-342/94, C-224/95, Rep. 1997, p.I-3561 (FJ 49); i de 15 de juny de 2000, ARCO Chemie Nederland $i$ altres, as. C-418/97 i C419/97, Rep. 2000, p.I-4475 (FJ 6).
} 
Per això, podria resultar determinant per a la no consideració d'una substància resultant d'un procés productiu com residu el fet de que gràcies a l'ús d'aquesta matèria es dóna compliment al principi de correcció en la font mateixa, en la mesura que amb una determinada substància combustible s'eviti en gran mesura el consum d'altres matèries primeres i els impactes ambientals que aquestes generin, a més del seu elevat cost. A això s'afegeix que la valorització de substàncies procedents d'un procés de producció permet llur reincorporació a aquest procés, evitant així els impactes ambientals que la seva eventual eliminació tindria sobre el medi ambient.

C. Irrellevància de la possible reutilització econòmica de la substància o objecte en qüestió

La possible reutilització econòmica d'una substància no és un criteri determinant per afirmar si es tracta d'un residu o no. En concret, el TJCE ha manifestat que el concepte de residu inclou béns susceptibles de reutilització econòmica ${ }^{35}$.

D'això es deriva, per tant, que el concepte de residu no exclou, en principi, cap tipus de residus, subproductes industrials o altres substàncies resultants d'un procés de producció $^{36}$, i que poden ser residus les substàncies que formin part d'un procés de producció $^{37}$.

No obstant això, el criteri de la Comissió Europea en la seva Comunicació de 21 de febrer de 2007, apartat 3.3, considera que les característiques del material en termes d'idoneïtat per a una reutilització econòmica poden implicar que no s'hauria de considerar com a residu, modulant així aquest criteri jurisprudencial.

Així, encara que el TJCE ha manifestat que la possible reutilització econòmica d'una substància no és un criteri determinant per establir si es tracta d'un residu o no, el cert

\footnotetext{
${ }^{35}$ Sentències del TJCE de 10 de maig de 1995, Comissió c/ Alemanya, as. C-422/92, Rep. 1995, p.I-1097 (FJ 22); de 25 de juny de 1997, Tombesi, as. C-304/94, C-330/94, C-342/94, C-224/95, Rep. 1997, p.I3561 (FJ 47, 52 i 54); de 18 de desembre de 1997, Inter-Environnement Wallonie / Région wallonne, as. C-129/96, Rep.1997, p.I-7411 (FJ 31); de 15 de juny de 2000, ARCO Chemie Nederland $i$ altres, as. C418/97 i C-419/97, Rep. 2000, p.I-4475 (FJ 22).

${ }^{36}$ Sentència del TJCE de 18 de desembre de 1997, Inter-Environnement Wallonie / Région wallonne, as. C-129/96, Rep.1997, p.I-7411 (FJ 28).

${ }^{37}$ Sentència del TJCE de 18 de desembre de 1997, Inter-Environnement Wallonie / Région wallonne, as. C-129/96, Rep.1997, p.I-7411 (FJ 32 i 34).
} 
és que s'ha de tenir en consideració, en la mesura en que, si hi ha interès econòmic en la reutilització d'una substància, almenys prima facie pot presumir-se que no hi ha intenció de desprendre's de la substància en qüestió.

D. Irrellevància del tractament que pugui donar-se a la substància o objecte en qüestió

El fet de que amb una substància o objecte es faci una operació de les incloses com de valorització o eliminació no implica necessàriament que la substància o objecte en qüestió sigui un residu ${ }^{38}$. No obstant això, afirma el TJCE que una operació de valorització o eliminació pot ser indici de què s'està davant un residu ${ }^{39}$, i que una substància pot ser considerada residu si no se li pot donar un destí diferent que l'eliminació ${ }^{40}$.

El TJCE ha conclòs que el fet que un residu s'hagi sotmès a una operació de valorització no suposa un criteri determinant i unívoc per a concloure que aquesta substància o objecte sigui un residu, ni tampoc per a concloure que aquest residu ha deixat de ser-lo per convertir-se en una matèria primera secundària.

\section{E. Intencionalitat}

Segons aquest criteri del TJCE, una substància o objecte pot considerar-se com residu de producció, és a dir, com una substància subjecta a la normativa sobre residus, quan no ha estat buscat com a tal ${ }^{41}$.

\footnotetext{
38 Sentències del TJCE de 15 de juny de 2000, ARCO Chemie Nederland $i$ altres, as. C-418/97 i C419/97, Rep. 2000, p.I-4475 (FJ 49 a 51, 64, 82, 95 i 97); i de 18 d'abril de 2002, Palin Granit and Vehmassalon kansaterveystyön kuntayhtymän hallitus, as. C-9/00, Rep. 2002, p.I-3533 (FJ 27).

${ }^{39}$ Sentència del TJCE de 15 de juny de 2000, ARCO Chemie Nederland $i$ altres, as. C-418/97 i C-419/97, Rep. 2000, p.I-4475 (FJ 47, 68, 69, 73, 95 a 97); i Interlocutòria del TJCE de 15 de gener de 2004, Saetti and Frediani, as. C-235/02, Rep. 2004, p.I-1005 (FJ 39).

${ }^{40}$ Sentència del TJCE de 15 de juny de 2000, ARCO Chemie Nederland $i$ altres, as. C-418/97 i C-419/97, Rep. 2000, p.I-4475 (FJ 86); i Interlocutòria del TJCE de 15 de gener de 2004, Saetti and Frediani, as. C235/02, Rep. 2004, p.I-1005 (FJ 39).

${ }^{41}$ Sentències del TJCE de de 15 de juny de 2000, ARCO Chemie Nederland $i$ altres, as. C-418/97 i C419/97, Rep. 2000, p.I-4475 (FJ 84); de 18 d'abril de 2002, Palin Granit and Vehmassalon kansaterveystyön kuntayhtymän hallitus, as. C-9/00, Rep. 2002, p.I-3533 (FJ 32); Interlocutòria del TJCE de 15 de gener de 2004, Saetti and Frediani, as. C-235/02, Rep. 2004, p.I-1005 (FJ 45 i 47).
} 
No obstant això, el TJCE ha matisat aquesta afirmació en la seva Sentència d'11 de novembre de 2004, Niselli, as. C-457/02, Rep. 2004, p.I-10853 (FJ 44), on ha dit que “pot admetre's una interpretació que consideri que un bé, un material o una matèria primera que resulta d'un procés de fabricació o d'extracció que no està destinat principalment a produir-lo pot constituir no un residu, sinó un subproducte del que l'empresa no desitja “desprendre's" en el sentit de l'article 1, lletra a), paràgraf primer, de la Directiva 75/442, però que té la intenció d'explotar o comercialitzar en circumstàncies que li siguin avantatjoses, en un procés ulterior sense operació de transformació prèvia".

Per tant, el fet que la substància o objecte en qüestió sigui el resultat d'un procés productiu i no hagi estat buscat com a tal, no necessàriament significa que es tracti d'un residu; per contra, si la substància o objecte resultant d'aquest procés ha estat buscada amb la intencionalitat de poder reutilitzar-la mitjançant la seva incorporació a un procés productiu posterior sense prèvia transformació, es pot considerar que s'està davant d'una matèria primera secundària, no subjecta, per tant, a la normativa sobre residus ${ }^{42}$.

\section{F. Opinió de la societat}

En ocasions, el TJCE ha manifestat que l'opinió de la societat sobre una substància pot constituir un indici de l'existència d'un residu ${ }^{43}$. Cal ressaltar, no obstant això, que el propi Tribunal ha observat que aquest element no resulta pertinent, tenint en compte el tenor literal del concepte de residu que s'esmenta en l'actual article 3.1 de la Directiva Marc, i de l'imprecís i vague dels seus termes.

\subsection{Biorresidu}

Altre aspecte significatiu de la nova Directiva Marc ha consistit en la definició legal de biorresidu com residu biodegradable de jardins i parcs, residus alimentaris i de cuina procedents de llars, restaurants, serveis de restauració col·lectiva i establiments de

\footnotetext{
${ }^{42}$ SERRANO PAREDES, O., "Aportaciones recientes de la jurisprudencia del TJCE en torno al concepto de residuo: los llamados 'indicios"', Revista Aranzadi de Derecho Ambiental, núm. 6, 2004, p. 134ss.

${ }^{43}$ Sentència del TJCE de 15 de juny de 2000, ARCO Chemie Nederland $i$ altres, as. C-418/97 i C-419/97, Rep. 2000, p.I-4475 (FJ 71); Interlocutòria del TJCE de 15 de gener de 2004, Saetti and Frediani, as. C235/02, Rep. 2004, p.I-1005 (FJ 39 i 46).
} 
consum al detall, i residus comparables procedents de plantes de transformació d'aliments.

Atès que els Estats membres són lliures per prendre mesures per estimular la recollida, tractament $\mathrm{i}$ ús de materials produïts a partir de biorresidus, amb vista a obtenir un alt grau de protecció del medi ambient, la Comissió haurà de realitzar una avaluació amb la intenció de proposar mesures legislatives en relació amb la gestió dels biorresidus, de conformitat amb allò previst en l'Exposició de Motius de la Directiva Marc ${ }^{44}$.

\subsection{Subproducte}

La Directiva Marc incorpora, recollint la jurisprudència comunitària, dos nous conceptes: subproducte i matèria primera secundària. La conseqüència principal de no qualificar-los com a residus és la no aplicació del règim d'intervenció i control administratiu d'aquests últims.

El TJCE va introduir el concepte de subproducte distingint-lo del de residu en diverses sentències ${ }^{45}$ tot indicant que:

“[...], de la jurisprudència del Tribunal de Justícia també es desprèn que, en determinades circumstàncies, un bé, un material o una matèria primera que resulti d'un procés d'extracció o de fabricació que no està destinat principalment a produir-lo pot constituir no un residu, sinó un subproducte del que el posseïdor no desitja «desprendre's», en el sentit de l'article 1, lletra a) de la Directiva [2006/12/CE de 5 d'abril, relativa als residus], sinó que té intenció d'explotar o comercialitzar - fins i tot, si escau, per a les necessitats d'altres operadors econòmics diferents del que l'ha produï -, en circumstàncies que li siguin avantatjoses, en un procés ulterior, sempre que aquesta reutilització sigui segura, no necessiti transformació prèvia i es situï sense solució de continuïtat en el procés de producció o d'utilització".

\footnotetext{
${ }^{44}$ En aquest sentit, l'apartat 35 de l'Exposició de Motius estableix: "En consonància amb la jerarquia de residus i amb l'objecte de reduir l'emissió de gasos d'efecte hivernacle originats per l'eliminació de residus en abocadors, és important facilitar la recollida separada i el tractament adequat dels biorresidus, per produir un compost segur per al medi ambient $\mathrm{i}$ altres materials basats en els biorresidus. La Comissió, prèvia avaluació de la gestió dels biorresidus, presentarà, si escau, propostes de mesures legislatives".
} 
La Directiva Marc en l'article 5, que és un article diferent al referit a les definicions, defineix subproducte en la mateixa línia que ho ha fet el TJCE:

“Una substància o objecte, resultant d'un procés de producció, la finalitat primària de la qual no sigui la producció d'aquesta substància o objecte, pot ser considerada com a subproducte i no com a residu conforme a l'article 3 , punt 1 , únicament si es compleixen les següents condicions:

a) és segur que la substància o objecte serà utilitzat ulteriorment;

b) la substància o objecte pot utilitzar-se directament sense haver de sotmetre's a una transformació ulterior diferent de la pràctica industrial normal;

c) la substància o objecte es produeix com a part integrant d'un procés de producció; i

d) l'ús ulterior és legal, és a dir, la substància o objecte compleix tots els requisits pertinents per a l'aplicació específica relatius als productes i a la protecció del medi ambient i de la salut, i no produirà impactes generals adversos per al medi ambient o la salut humana".

\subsection{Fi de la condició de residu}

Una vegada més, en íntima relació amb la doctrina assentada pel TJCE, la Directiva Marc ha dedicat un article a definir les situacions en les quals determinats residus deixen de tenir aquesta condició.

En aquest context, serà convenient analitzar la doctrina establerta pel Tribunal en la que s'indicava quan un residu deixava de ser-ho per convertir-se en una matèria primera secundària apta per a la seva reincorporació a un procés productiu. El TJCE ha conclòs que "una substància únicament deixa de ser residu quan ha estat objecte d'una operació de valorització completa", és a dir, "quan pot ser tractada de la mateixa manera que una matèria primera" 46 .

\footnotetext{
${ }^{45}$ Entre d'altres, Sentències del TJCE 18 de desembre de 2007, Comissió c/ Itàlia, as. C-194/05, Rep. 2007, p.I-11661 (FJ 38), d'11 de setembre de 2003, AvestaPolarit Chrome, as. C-114/01, Rep. 2003, p.I8725 (FJ 34); i d'11 de novembre de 2004, Niselli, as. C-457/02, Rep. 2004, p.I-10853 FJ 47).

${ }^{46}$ Sentència del TJCE de 15 de juny de 2000, ARCO Chemie Nederland $i$ altres, as. C-418/97 i C-419/97, Rep. 2000, p.I-4475 (FJ 93), entre d'altres.
} 
De forma resumida, tres són els requisits per considerar una operació de valorització com completa segons el $\mathrm{TJCE}^{47}$. En primer lloc, que els residus siguin tractats o valorizats amb la finalitat principal de que puguin complir una funció útil. A més, que el resultant del procés de valorització es reutilitzi en un procés productiu de la mateixa manera que una matèria primera sense necessitat de cap operació de transformació o tractament previ, constituint, per tant, una reutilització no només possible, sinó també segura. I finalment, la utilització del resultant del procés de valorització substitueixi l'ús d'altres materials o matèries primeres que haguessin hagut d'emprar-se per assolir la mateixa finalitat, el que permet preservar els recursos naturals.

En atenció a l'esmentada jurisprudència s'ha redactat l'article 6 de la Directiva Marc que es refereix a les matèries primeres secundàries, establint-se en el seu primer apartat, que determinats residus específics deixaran de ser residus quan hagin estat sotmesos a una operació de valorització, inclòs el reciclat, i compleixin els criteris específics que s'elaborin d'acord amb les següents condicions:

a) la substància o objecte s'utilitza normalment per a finalitats específiques;

b) existeix un mercat o una demanda per a aquesta substància o objecte;

c) la substància o objecte satisfà els requisits tècnics per a les finalitats específiques, i compleix la legislació existent i les normes aplicables als productes; i

d) l'ús de la substància o objecte no generarà impactes adversos globals per al medi ambient o la salut.

\section{Responsabilitat ampliada del productor}

La Directiva Marc habilita els Estats membres per adoptar mesures legislatives per garantir que qualsevol persona física o jurídica que desenvolupi, fabriqui, processi, tracti, vengui o importi productes de forma professional, això és, el productor del producte, vegi ampliada la seva responsabilitat de productor a les fases de gestió dels

\footnotetext{
${ }^{47}$ Per totes, vegin-se les Sentències del TJCE de 19 de juny de 2003, Mayer Parry Recycling, as. C444/00, Rep. 2003, p.I-6163 (FJ 63); i de 27 de febrer de 2002, ASA, as. C-6/00, Rep. 2002, p.I-1961 (FJ 69).
} 
residus derivats dels seus productes i, en particular, a l'obligació de finançar aquestes activitats.

Per a la consecució d'aquest objectiu, les mesures proposades en la Directiva Marc abasten, a títol d'exemple: (a) el disseny de productes de manera que redueixin el seu impacte ambiental i la generació de residus durant la producció i subsegüent utilització dels productes, especialment el disseny de productes reutilitzables, duradors i amb característiques que facilitin el seu reciclat; (b) el tractament dels residus en nom de per aquest ordre - la prevenció, reutilització, reciclat, altres valoritzacions com l'energètica i l'eliminació, tot salvaguardant la protecció de la salut humana i el medi ambient.

No obstant això, la responsabilitat ampliada que imposin els Estats membres en aplicació de la responsabilitat ampliada haurà de tenir en compte: (i) la viabilitat tècnica i econòmica ${ }^{48}$; (ii) el conjunt d'impactes ambientals, sobre la salut humana i social; i (iii) el respecte al correcte funcionament del mercat interior, qüestió aquesta última, que en un primer moment emfatitza l'exposició de motius.

La Llei 10/1998 ja havia regulat en els seus articles 7 i 8 l'enfocament de la responsabilitat ampliada del productor en termes similars als establerts en la Directiva Marc. No obstant això, inclou un element que no esmenta la Directiva Marc: la possibilitat de que, per al compliment de totes o algunes de llurs obligacions, els responsables de l'entrada en el mercat de productes que amb l'ús es transforma en residus puguin organitzar sistemes propis de gestió mitjançant la celebració d'acords voluntaris aprovats o autoritzats per les Administracions Públiques competents o mitjançant convenis de col·laboració amb aquestes ${ }^{49}$.

\footnotetext{
48 La imposició d'aquest condicionament s'assembla al concepte de les "disponibles" previst en la Directiva 96/61/CE, del Consell, de 24 de setembre, relativa a la prevenció i al control integrat de la contaminació i la Llei 16/2002, d'1 de juliol, de prevenció i control integrats de la contaminació que la incorpora a l'ordenament espanyol, al referir-se a les millors tècniques disponibles com aquelles desenvolupades a una escala que permeti la seva aplicació en condicions econòmiques i tècnicament viables.

49 Referent a això, la legislació espanyola vigent sobre envasos, vehicles al final de la seva vida útil, aparells elèctrics i pneumàtics fora d'ús, olis industrials usats i piles i acumuladores ha concretat la regulació de la responsabilitat ampliada del productor per a cada flux de residu. El problema radica que aquesta normativa emmalalteix de falta d'homogeneïtat, derivat del fet que aborda fluxos de residus de sectors amb característiques molt heterogènies. És per això, pel que el Ministeri ja s'ha pronunciat sobre la necessitat de buscar una major homogeneïtat en l'enfocament de la responsabilitat ampliada del productor.
} 


\section{Jerarquia de residus}

Una altra de les modificacions introduïdes per la Directiva Marc consisteix en la nova jerarquia de residus, que servirà d'ordre de prioritats en la legislació i la política sobre la prevenció i la gestió de residus dels Estats membres. La prelació d'objectius marcats en el seu article 4, segueix el següent ordre: (a) la prevenció; (b) la reutilització; (c) el reciclat; (d) altres tipus de valorització, com per exemple, la valorització energètica; i finalment (e) l'eliminació.

Per primera vegada la Directiva Marc defineix cadascun d'aquests conceptes. Ens centrarem en aquest apartat en els tres primers, donada la importància que els atorga la Directiva Marc.

En concret, l'article 4 defineix el concepte de prevenció com:

“mesures adoptades abans de que una substància, material o producte s'hagi transformat en residu, per reduir:

a) la quantitat de residu, fins i tot mitjançant la reutilització dels productes o l'allargament de la vida útil dels productes;

b) els impactes adversos sobre el medi ambient i la salut humana de la generació de residus, o

c) el contingut de substàncies nocives en materials i productes".

En aquest context, la Directiva Marc conté un mandat als Estats membres perquè elaborin, abans del 12 de desembre de 2013, programes de prevenció de residus que establiran objectius de prevenció de residus i descriuran les mesures de prevenció existents i avaluaran l'ús de mesures que s'indiquen. La finalitat d'aquests objectius serà trencar el vincle entre el creixement econòmic i els impactes mediambientals associats a la generació de residus.

En relació amb la definició de reutilització i reciclat, pel primer s'entén “qualsevol operació mitjançant la qual productes o components que no siguin residus s'utilitzen de nou amb la mateixa finalitat per a la qual van ser concebuts" i, pel segon, "tota operació de valorització mitjançant la qual els materials de residus són transformats de nou en productes, materials o substàncies, tant si és amb la finalitat original com amb qualsevol altra finalitat. Inclou la transformació del material orgànic, però no la valorització energètica ni la transformació en materials que es vagin a utilitzar com combustibles o per a operacions de farciment”. 
La Directiva Marc, en el seu article 11, estableix que els Estats membres prendran les mesures que escaiguin per fomentar la reutilització dels productes i les activitats de preparació per a la reutilització, promovent l'establiment i suport de xarxes de reutilització i reparació, l'ús d'instruments econòmics, els requisits de licitació, els objectius quantitatius o altres mesures.

Per la seva banda, els Estats membres han de fomentar un reciclat d'alta qualitat i, per complir amb els criteris de qualitat necessaris per als sectors de reciclat corresponents, establir una recollida separada de residus, quan sigui tècnica, econòmica i ambientalment factible i adequada. És per això que la Directiva Marc estableix com a termini màxim l'any 2015 per a què es realitzi la recollida separada, d'almenys, les matèries següents: paper, metalls, plàstic i vidre.

A més, s'obliga als Estats membres a adoptar les mesures necessàries per a garantir que s'assoleixen els següents objectius en matèria de reutilització de reciclat:

a) Abans de l'any 2020, haurà d'augmentar-se com a mínim fins a un 50\% global del seu pes la preparació per a la reutilització i el reciclat de residus de materials tals com, almenys, el paper, els metalls, el plàstic $\mathrm{i}$ el vidre dels residus domèstics $\mathrm{i}$ possiblement d'altres orígens en la mesura en que aquests fluxos de residus siguin similars als residus domèstics.

b) Abans de l'any 2020, haurà d'augmentar-se fins a un mínim del 70\% del seu pes la preparació per a la reutilització, el reciclat i altra valorització de materials, incloses les operacions de farciment que utilitzin residus com succedanis d'altres materials, dels residus no perillosos procedents de la construcció i de les demolicions, a exclusió dels materials presents de manera natural ${ }^{50}$.

A l'efecte de comprovar el compliment dels anteriors objectius, la Comissió establirà normes sobre l'aplicació i mètodes de càlcul per verificar el compliment dels objectius establerts, que podran incloure períodes de transició per als Estats que reciclin menys del 5\% de cadascuna de les categories esmentades, durant l'exercici 2008. 


\section{Valorització}

La Directiva Marc exigeix que els Estats membres adoptin mesures per garantir que tots els residus es sotmetin a operacions de valorització de conformitat amb la jerarquia de residus que s'acaba d'exposar, respectant la salut humana i sense fer malbé el medi ambient.

De nou la Directiva Marc defineix el concepte de valorització. No obstant això, a diferència del que succeïa en la Directiva 2006/12/CE, de 5 d'abril, relativa als residus, en la qual simplement remetia aquestes operacions a les enumerades en l'annex II B, la Directiva Marc inclou en la seva definició principis establerts pel TJCE sobre quan un residu pot entendre's totalment valoritzat, de tal manera que la definició queda de la següent manera:

“Cualquier operación cuyo resultado principal sea que el residuo sirva a una finalidad útil al sustituir a otros materiales que de otro modo se habrían utilizado para cumplir una función particular, o que el residuo sea preparado para cumplir esa función, en la instalación o en la economía en general. En el anexo II se recoge una lista no exhaustiva de operaciones de valorización".

Atenent a les operacions concretes de valorització que recull l'Annex II, cal fer esment a la primera d'elles: "Utilització principal com a combustible o altra manera de produir energia", aclarint a continuació que s'inclouen en aquest epígraf les instal-lacions d'incineració destinades al tractament de residus sòlids urbans només quan la seva eficiència energètica resulti igual o superior a determinats paràmetres.

Aquesta precisió intenta donar solució als conflictes plantejats davant del TJCE pels quals es plantejava si la crema de residus havia de qualificar-se com operacions de valorització o eliminació. ${ }^{51}$

\footnotetext{
${ }^{50}$ Definits en la categoria 170504 de la llista europea de residus, és a dir, terra i pedres diferents de les que continguin substàncies perilloses.

${ }^{51}$ En la Sentència del TJCE de 13 de febrer de 2003, Comissió c/ Luxemburg, as. C-458/00, Rep.2003, p.I-1553, es va deixar clar que no es pot considerar que la incineració de residus en una instal·lació de tractament concebuda per a l'eliminació de residus tingui com objectiu principal la valorització de residus, tot i que durant la seva incineració es procedeixi a la recuperació total o parcial de la calor produïda per la combustió. D'altra banda, la Sentència de la mateixa data dictada en un assumpte de la Comissió contra Alemanya si que va indicar que en els supòsits d'utilització de residus com combustible en els forns de ciment sí té consideració d'operació de valorització, ja que l'operació persegueix l'objectiu de permetre l'ús de residus com a mitjà per a generar energia, ocupant per tant una funció útil,
} 
Finalment, cal ressenyar que en aquells casos en els quals no es porti a terme la valorització segons allò indicat anteriorment, el residu es sotmetrà a operacions d'eliminació ${ }^{52}$ segures, segons la 1lista prevista en 1'Annex I. Per tant, com la Directiva ha indicat que "tots" els residus han de sotmetre's a operacions de valorització, sembla que el que es pretén és que l'activitat d'eliminació només hagi d'escometre's en els supòsits de "residus del residu".

\section{Autoritzacions}

Tal i com s'ha analitzat anteriorment, sota el marc legislatiu actual previst en la Llei 10/1998 el règim d'autoritzacions podria resumir-se de la següent manera: (a) es requereix autorització per a la instal·lació, ampliació i modificació substancial de les indústries i activitats productores de residus; (b) les activitats de valorització i eliminació queden sotmeses al règim d'autorització excepte en el cas de gestió de residus urbans realitzats per les pròpies entitats locals; i (c) la realització pel productor de les activitats de valorització i eliminació dels seus propis residus no perillosos en els centres de producció pot quedar eximida d'autorització, i en aquest cas seran registrades.

No obstant això, la Directiva Marc ha previst que els Estats membres exigeixin a qualsevol entitat o empresa que tingui intenció de portar a terme el tractament de residus que obtingui una autorització de l'autoritat competent.

El contingut mínim de l'autorització es recull en l'article 23 de la Directiva Marc.

Així, haurà de contenir, com a mínim:

a) els tipus i quantitats de residus que poden tractar-se;

b) per a cada tipus d'operació autoritzada, els requisits tècnics i de qualsevol altre tipus aplicables al lloc corresponent;

c) les mesures de seguretat i precaució que hauran de prendre's;

substituint l'ús d'altres materials que haguessin hagut d'emprar-se per a ocupar aquesta comesa, el que permet preservar els recursos naturals.

52 S'entén per "eliminació" qualsevol operació que no sigui la valorització, fins i tot quan l'operació tingui com a conseqüència secundària l'aprofitament de substàncies o energia (art. 3.20 de la Directiva Marc). 
d) el mètode que s'utilitzarà per a cada tipus d'operació;

e) les operacions de supervisió i de control que puguin resultar necessàries;

f) les disposicions relatives al tancament i al manteniment posterior que puguin ser necessàries.

Cabrà eximir de responsabilitat a les entitats o empreses que realitzin les següents operacions: (i) l'eliminació dels seus propis residus no perillosos en el lloc de producció, o (ii) la valorització de residus.

Per poder concedir aquestes exempcions és necessari que els Estats membres estableixin per a cada tipus d'activitat, normes que delimitin els tipus i quantitats de residus als quals pugui aplicar-se l'exempció, així com els mètodes de tractament que hagin d'emprar-se.

En aquells casos en què les entitats que transporten residus amb caràcter professional, els negociants o agents, o les entitats que realitzin les activitats citades anteriorment estan exemptes dels requisits d'autorització, els Estats membres s'asseguraran que les autoritats duguin un registre d'aquestes.

Cal ressaltar que en l'àmbit de residus perillosos la nova Directiva no exigeix autorització per als productors de residus perillosos, a diferència del que es preveu a la normativa espanyola.

\section{AVENÇOS EN LA TRANSPOSICIÓ DE LA DIRECTIVA MARC}

La Directiva Marc haurà d'estar incorporada al dret espanyol abans del 12 de desembre d'aquest any. Per aquest motiu, el Ministeri està realitzant, a través del Grup de Treball de Residus del Consell Assessor de Medi Ambient, els estudis pertinents per preparar un esborrany de Projecte de Llei, el qual, una vegada incorporat a l'ordenament, derogui la Llei $10 / 1998^{53}$.

En línies generals, la nova norma perseguirà simplificar i modernitzar la legislació de residus existent, tot aplicant una política de prevenció de residus més ambiciosa i eficaç.

\footnotetext{
${ }^{53}$ Tal com s'ha avançat en la introducció del present estudi, el grup de treball va fer públic el passat dia 19 de gener de 2010 un document que esquematitzava les línies bàsiques que seguirà la nova Llei, que incloïa l'índex a seguir per l'esborrany de la norma. Sobre aquest document es basaran les conclusions recollides en el present apartat.
} 
A aquests efectes, la nova norma haurà de promoure la transparència, l'eficàcia ambiental i econòmica de les activitats de gestió de residus, i intentar donar una solució al deficient marc regulador actual dels residus municipals o urbans.

En la direcció marcada per la Directiva Marc, la futura Llei haurà de promoure la reutilització i el reciclat, així com harmonitzar la regulació existent en algunes Comunitats Autònomes de la responsabilitat ampliada del productor i, vinculat a això, homogeneïtzar els sistemes integrats de gestió.

Exposat l'anterior, en els següents apartats partirem dels aspectes tractats en estudiar la Directiva Marc per passar a analitzar quines són les novetats que hauria de recollir la nova norma estatal en relació amb residus urbans, biorresidus, autoritzacions, residus perillosos i responsabilitat ampliada del productor.

\section{Residus urbans}

\subsection{Concepte de residu urbà i la seva gestió}

En matèria de residus urbans, des del Ministeri es planteja la possible existència d'una problemàtica per les diferents interpretacions que pogués donar-se a l'abast de la definició de residus urbans, principalment en matèria de "residus assimilables a domèstics". La solució que es planteja, als efectes de donar resposta a aquest problema, és la d'incloure definicions de residu domèstic, comercial i industrial, en substitució de residu urbà. Aquesta delimitació conceptual permetria a la seva vegada delimitar perfectament la responsabilitat de gestió per a cada un dels agents intervinents, i, en particular, la responsabilitat que pogués correspondre a les entitats locals.

El concepte de "residu domèstic" comprendria els residus generats a les llars com a conseqüència de les activitats domèstiques com són residus de cuina, de poda, de paper i cartró, de plàstics i de vidre, entre d'altres. S'inclouen també els residus d'aparells elèctrics i electrònics, roba, piles, mobles i estris que es generen dins de les llars. La responsabilitat de la gestió en aquesta categoria correspondria a les entitats locals, però el posseïdor haurà de lliurar els residus en les condicions que aquestes determinin a través de les seves respectives ordenances. Les entitats locals hauran de deixar com a servei obligatori la recollida, el transport, la valorització i l'eliminació d'aquest tipus de residus. 
Els "residus comercials" inclourien aquells generats en les activitats comercials, a l'engròs i al detall, en els serveis de restauració i càtering a les oficines i en els mercat municipals, així com en el sector dels serveis. A efectes de la gestió tenen la categoria de residu comercial aquells residus de composició i naturalesa similar a la dels residus domèstics, que es generen en la indústria. En aquests casos resultaria responsable de la seva gestió la persona titular de l'activitat. Per al compliment de les seves obligacions, el responsable podrà optar entre gestionar els residus per sí mateix, lliurar-los a un gestor autoritzat o acollir-se al sistema de recollida i gestió que l'ens local competent estableixi per a aquest tipus de residus, incloent el possible ús dels punts nets.

Finalment, s'entendrien com "residus industrials" aquells residus sòlids, líquids i gasosos resultants d'un procés de fabricació, de transformació, d'utilització, de consum o de neteja generats en les indústries. La responsabilitat en la gestió dels residus industrials seria del seu productor i del seu posseïdor.

\subsection{Recollida separada de residus per al seu adequat reciclat}

Tal com s'ha avançat, en matèria de recollida separada de residus, la Directiva Marc estableix que abans de 2015 s'haurà d'efectuar una recollida separada per a, almenys, les matèries següents: paper, metalls, plàstic i vidre. I que, no més tard de 2020 , s'haurà d'augmentar com a mínim fins i tot un 50\% global del seu pes la preparació per a la reutilització i el reciclat de residus de materials com ara, almenys, el paper, els metalls, el plàstic i el vidre dels residus domèstics i possiblement d'altres orígens en la mesura que aquests fluxos de residus siguin similars als residus domèstics.

En relació amb aquesta matèria, hem de recordar que en l'actualitat la legislació estatal espanyola és deficitària. En efecte, la Llei 10/1998 va preveure l'obligació municipal de comptar amb un servei de recollida selectiva per a aquells municipis amb una població superior a 5.000 habitants a partir de 2001 i, per la seva banda, la Llei 11/1997, de 24 d'abril, d'envasos i residus d'envasos ja havia instaurat la recollida periòdica dels envasos usats $\mathrm{i}$ dels residus d'envasos, al domicili del consumidor o en les seves 
proximitats a través dels anomenats sistemes integrats de gestió de residus d'envasos i envasos usats ${ }^{54}$.

Malgrat que la regulació està molt allunyada del que predica la Directiva, el Ministeri entén que pot servir de base per establir la futura transposició. En efecte, s'han previst diferents modalitats que parteixen dels principis continguts en les normes citades. El Ministeri contempla quatre modalitats diferents entre les que s'ha d'optar per dur a terme la recollida separada de residus: (a) la recollida de monomateriales de plàstic, paper, vidre, metalls i fracció orgànica, quedant una fracció residual amb els altres materials; (b) la recollida monomaterial de fracció orgànica, paper, de vidre i un únic contenidor per a plàstics i metalls —independentment de la seva consideració com a envasos_-, quedant un altre contenidor per a la resta; (c) la recollida monomaterial de paper, cartró, vidre i fracció orgànica i un altre contenidor per a la resta —això és, plàstic i metalls i d'altres_-; i (d) recollida monomaterial de fracció orgànica i paper, cartró, envasos lleugers i envasos de vidre, quedaria un contenidor per a la fracció residual on aniria plàstic i metalls no envasos, entre d'altres.

\section{Biorresidus}

D'acord amb el text de la Directiva Marc, els "biorresidus" són residus biodegradables de jardins i parcs, residus alimentaris i de cuina procedents de llars, restaurants, serveis de restauració col-lectiva i establiment de consum al detall, i residus comparables, procedents de plantes de transformació d'aliments. En aquest sentit, és l'Estat qui ha de fomentar que es prenguin les mesures necessàries per impulsar la recollida separada de biorresidus amb vista al compostatge i a la seva digestió.

La Directiva Marc incideix en la necessitat d'adoptar les mesures pertinents per al tractament de biorresidus de tal manera que s'aconsegueixi un alt grau de protecció del medi ambient i, a aquests efectes, prioritza l'ús de materials ambientalment segurs produïts a partir de biorresidus.

Per a la consecució d'aquests fins, el Ministeri valora la possibilitat d'incloure objectius percentuals graduats en el temps de recollida separada dels biorresidus ${ }^{55}$, tot deixant a

\footnotetext{
54 POVEDA GÓMEZ, P., Envases y residuos de envases. Nueva legislación. Comentarios a la Ley
} 11/1997, de 24 de abril, Exlibris Ediciones, Madrid, 1997, p. 114ss. 
les mans de les entitats locals la decisió sobre la metodologia a seguir. En aquest sentit, el Ministeri proposa com formes per dur a terme els objectius marcats per la Directiva Marc: el compostatge domèstic, la recollida separada de la fracció vegetal, la recollida en grans generadors o la recollida de la fracció orgànica de residus domèstics.

En tot cas, la manca de claredat sobre l'abast de la definició de residu urbà i, especialment, en matèria dels "residus assimilables a domèstics", podria generar problemes a la pràctica. Anticipant el problema, el Ministeri proposa salvar aquest escull incloent la definició de residu domèstic, comercial i industrial, en substitució de residu urbà o bé proposant la responsabilitat de gestió per a cada un dels subjectes intervinents establint el que haurien de realitzar les entitats locals en cada cas.

\section{Règim regulador}

\subsection{Autoritzacions, comunicacions i llibre registre}

En matèria d'autoritzacions, el Ministeri té previst ajustar el nou marc regulador als termes de la Directiva Marc.

En aquest sentit, la norma recollirà els supòsits en els quals sigui necessari demanar una autorització, el procediment a seguir i aquells supòsits exempts d'autorització o que han de ser substituïts per una comunicació.

En relació amb l'autorització, estaran subjectes a ella aquelles entitats o empreses que tinguin la intenció de dur a terme el tractament de residus. L'entitat competent per tramitar l'autorització serà la Comunitat Autònoma on s'ubiqui la instal·lació, com venia succeint fins ara. La Comunitat Autònoma serà, per tant, l'encarregada de realitzar la comprovació prèvia de les instal-lacions on es dugui a terme el tractament

\footnotetext{
recollida separada del biorresidus amb les següents fites:

a) $10 \%$ de biorresidu recollit selectivament respecte del total generat al 2012 .

b) $20 \%$ de biorresidu recollit selectivament respecte del total generat al 2014 .

c) $35 \%$ de biorresidu recollit selectivament respecte del total generat al 2017 .

d) $50 \%$ de biorresidu recollit selectivament respecte del total generat al 2020 .
}

55 Així mateix, el Ministeri s'està plantejant un calendari als efectes de complir amb els objectius de 
dels residus i la que haurà de resoldre sobre la procedència de l'atorgament de l'autorització ${ }^{56}$.

Pel que fa als supòsits que, atenent a la Directiva, estan exempts d'autorització, el Ministeri té pensat delegar en els Governs central i autonòmics l'aprovació de les regles a aplicar per als supòsits d'exempció.

Quant al règim de comunicació, recordem que la Directiva Marc estableix que estan subjectes a aquest règim les entitats o empreses que recullen o transporten residus amb caràcter professional, els negociants o agents que adquireixin o importin residus $\mathrm{i}$ les entitats o empreses exemptes d'autorització segons s'estableixi. En aquests supòsits el Ministeri considera que els obligats hauran de presentar una comunicació davant de l'òrgan ambiental competent de la Comunitat Autònoma.

Les autoritzacions i comunicacions a què acabem de fer referència s'hauran d'inscriure per les Comunitats Autònomes en el registre de producció i gestió de residus que es desenvoluparà reglamentàriament per cada una de les Comunitats.

Pel que fa referència a l'obligació de portar un llibre registre cronològic, la nova norma exigirà el compliment d'aquesta obligació a les entitats o empreses que obtinguin l'autorització per al tractament de residus, als productors de residus perillosos, a les empreses que recullin o transportin residus amb caràcter professional i als negociants o agents que adquireixin o importin residus. La informació continguda en aquest llibre s'haurà d'enviar anualment a les Comunitats Autònomes, les quals hauran d'informar al Ministeri perquè aquest traslladi les referides dades a la Comissió Europea.

\subsection{Fi de la condició de residu i subproducte}

Respecte a allò previst per la Directiva Marc en relació amb el fi de la condició de residu, tal com s'ha vist, la mateixa norma estableix que determinats residus específics deixaran de ser residus quan hagin estat sotmesos a una operació de valorització i compleixin els criteris que específicament per a aquest tipus de residu elaborin les

\footnotetext{
56 A l'hora de decidir sobre la concessió de l'esmentada autorització, la Comunitat Autònoma corresponent haurà de verificar el compliment dels requisits tècnics i professionals relatius a l'empresa que durà a terme el tractament, a la instal·lació on es realitzarà l'activitat $\mathrm{i}$ a les concretes operacions de tractament de residus, així com assegurar-se de que es prenen les mesures de seguretat pertinents.
} 
instàncies comunitàries $\mathrm{o}$, en el seu defecte, el Govern prèvia comunicació a la Comissió.

Doncs bé, el Ministeri té pensat afegir en la norma de transposició que els residus que deixin de ser residus atenent a la Directiva Marc deixaran també de ser residus als efectes dels objectius de valorització i reciclatge establerts en la normativa espanyola ${ }^{57}$.

Finalment, en matèria de subproductes, el Govern i les Comunitats Autònomes podran declarar que substàncies o objectes específics es consideraran subproductes i no residus, basant-se en les condicions establertes en la Directiva i en els criteris que determinin les instàncies comunitàries.

\section{Residus perillosos}

La Directiva Marc entén com a "residu perillós" aquell que presenta una o diverses característiques perilloses de les enumerades en la norma i totes aquelles substàncies o productes que pugui aprovar el Govern de conformitat amb allò establert en la normativa europea o en convenis internacionals dels quals Espanya sigui part.

Tal com s'ha exposat anteriorment, la Directiva Marc, contràriament al que preveu la norma espanyola, no estableix obligacions d'autorització per als productors de residus perillosos. Per això, el Ministeri considera que per adequar la legislació espanyola a allò previst en la norma comunitària, la nova norma haurà de substituir l'actual autorització per una comunicació a l'òrgan mediambiental competent de la Comunitat Autònoma.

\section{Responsabilitat ampliada del productor}

La Directiva Marc permet aplicar la responsabilitat ampliada del productor mitjançant l'adopció de mesures per incrementar i millorar la prevenció i la gestió dels residus. En efecte, són els Estats membres els que han de crear un marc general harmonitzat per a la seva aplicació i permetre enquadrar els sistemes ja establerts (sistemes de dipòsit

\footnotetext{
${ }^{57}$ Concretament, el previst en la Llei 11/1997, de 24 d'abril, d'envasos i residus d'envasos, en el Decret 1383, de 20 de desembre, sobre gestió de vehicles al final de la seva vida útil, en el Reial Decret 208/2005, de 25 de febrer, sobre aparells elèctric i electrònics i la gestió dels seus residus, en el Reial Decret 106/2008, d'1 de febrer, sobre piles i acumuladors i la gestió ambiental dels seus residus, en el Reial Decret 1619/2005, de 30 de desembre, sobre la gestió de pneumàtics fora d'ús, i en el Reial Decret $679 / 2006$, de 2 de juny, pel que es regula la gestió dels olis industrials utilitzats.
} 
devolució i retorn —SDDR—, sistemes integrats de gestió — $\mathrm{SIG}$-, sistemes organitzats de gestió, sistemes individuals de gestió, participació en sistema públic de gestió).

Amb aquest objectiu, els Estats membres s'han de pronunciar sobre algunes qüestions. Entre d'altres aspectes, l'Estat espanyol ha d'aclarir en la seva norma de transposició quins són els drets i obligacions en matèria de gestió dels productors, gestors i Administracions Públiques i els consumidors, i quines són les obligacions en matèria de finançament.

A aquests efectes, la norma de transposició haurà d'aclarir les funcions i relacions dels diferents sistemes que s'estableixin amb les Administracions Públiques i el paper dels acords voluntaris o els convenis de col-laboració entre les Administracions i els sistemes que es creïn a l'empara del principi de responsabilitat del productor. També és necessari que la norma fixi les quanties que s'hauran de carregar en el cost del producte, en el cas que n'hi hagi, i determinar el paper i la consideració de les entitats gestores dels sistemes i la seva figura jurídica (ja sigui bé entitats sense ànim de lucre, fundacions, societats o organismes públics) i les mesures concretes que s'han de prendre per garantir que els sistemes de gestió s'ajustin als principis de publicitat, concurrència i igualtat.

\section{LA INVOCABILITAT I L'EFICÀCIA DIRECTA DE LA DIRECTIVA MARC}

\section{Règim jurídic de les Directives comunitàries}

Una vegada analitzat el contingut normatiu de la Directiva Marc i les línies de treball per a la seva transposició, és procedent fer unes valoracions sobre la seva transcendència jurídica i efectes respecte de l'ordenament jurídic. En primer lloc, cal recordar que les Directives comunitàries són unes normes que tenen com a únics destinataris els Estats membres de la Unió Europea, i llur finalitat és harmonitzar les diverses regulacions nacionals. Aquesta harmonització es duu a terme segons allò disposat a l'article 288 del Tractat de funcionament de la Unió Europea, és a dir, “la directiva obligará al Estado miembro destinatario en cuanto al resultado que deba conseguirse, dejando, sin embargo, a las autoridades nacionales la elección de la forma y de los medios".

Per tant, les Directives comunitàries fixen uns objectius que hauran de ser assolits pels Estats membres, però correspon als Estats l'elecció dels instruments i vies per 
transposar als ordenaments jurídics interns les disposicions de la Directiva. Aquesta transposició ha de dur-se a terme abans de la finalització del "termini de transposició" que, com hem vist, en el cas de la Directiva Marc és el 12 de desembre de 2010.

Dels anteriors trets característics de les Directives, pot concloure's que aquestes únicament imposen obligacions als Estats membres, que en són els destinataris, i a llurs autoritats nacionals. L'obligació essencial és la de transposar correctament la Directiva a l'ordenament nacional dins del termini fixat per la transposició. Per aquest motiu, les Directives no poden invocar-se per imposar obligacions als particulars, ni tenen efectes vinculants respecte d'aquests ${ }^{58}$. En virtut del principi de seguretat jurídica, les obligacions imposades al particulars per una Directiva només seran efectives quan hagin estat transposades a l'ordenament jurídic intern de l'Estat membre ${ }^{59}$.

\section{Invocabilitat $i$ efecte directe vertical de la Directiva Marc: supòsit de reconeixement de drets als particulars}

Com acaba d'assenyalar-se, una Directiva no pot ser invocada per un Estat per imposar obligacions als particulars, en cas de manca de mesures nacionals de transposició. En canvi, una Directiva sí podrà invocar-se per un particular davant de les autoritats d'un Estat membre, quan aquesta li hagi reconegut un dret i concorrin determinades circumstàncies. Es tracta de l'anomenat efecte directe de les Directives comunitàries.

Aquest efecte directe és exclusivament vertical, això és, la Directiva només pot invocarse davant dels poder públics (i no, en principi, davant d'altres particulars) ${ }^{60}$. La raó de ser de l'efecte directe vertical de les Directives és que els seus destinataris són els Estats membres ${ }^{61}$. Per tant, si una Directiva obliga a un Estat membre a reconèixer un dret a un particular, aquest el podrà invocar i fer valer davant de les autoritats nacionals.

\footnotetext{
58 Sentència del TJCE de 17 d'octubre de 1985, Pretore di Salò, as. C-14/86, Rep. 1987, p.2545, i Sentència del TJCE de 8 d'octubre de 1987, Kolpinghuis Nijmegen, as. C-80/86, Rep. 1987, p.3969, entre d'altres. Aquest fenomen es coneix com l'exclusió de l'eficàcia vertical inversa de les Directives.

${ }^{59}$ RUIZ-JARABO COLOMER, D., El Juez nacional como Juez Comunitario, Civitas, Madrid, 1993, pp. $145-147$.

${ }^{60}$ Sentència del TJCE de 26 de febrer de 1986, Marshall, as. C-152/84, Rep. 1986, p.723.

${ }^{61} \mathrm{Ha}$ de tenir-se present que la referència als "Estats membres" com a responsables de la transposició adequada de les Directives ha de ser entès de manera àmplia, això és, a totes les instàncies $i$ autoritats competents de l'Estat membre, que tinguin les facultats per transposar la corresponent Directiva.
} 
Aquesta invocabilitat del dret reconegut per la Directiva requereix la finalització del termini fixat per la transposició de la Directiva sense que hagi estat duta a terme la seva transposició de manera adequada ${ }^{62}$ per part de 1'Estat membre. La deficient transposició pot consistir tant en una absència d'aprovació de normes nacionals de transposició, com en l'aprovació de normes de transposició inadequades o insuficients o, fins i tot, contràries a la Directiva.

En aquest escenari, cal tenir present que el conflicte entre una disposició de Dret comunitari i una de l'ordenament jurídic nacional intern d'un Estat membre ha de solucionar-se a la llum dels principis de primacia $^{63}$ i d'efecte $\operatorname{directe}^{64}$ del Dret comunitari.

El principi de primacia suposa que les normes de Dret comunitari prevalen sobre les normes nacionals que les contradiguin. El principi d'efecte directe consisteix en què les disposicions de Dret comunitari que reconeguin drets o imposin obligacions puguin ser exercitables i exigibles. A aquests efectes, aquestes normes de Dret comunitari han de reunir determinats requisits identificats per la jurisprudència del TJCE.

La conjunció d'ambdós principis es materialitza en la inaplicabilitat de les normes nacionals dels Estats membres que entrin en conflicte amb elles. Els jutges nacionals tenen el deure -imposat pel Dret comunitari- d'inaplicar d'ofici qualsevol norma del seu ordenament jurídic intern que entri en conflicte amb una disposició de Dret comunitari $^{65}$, sense haver de plantejar cap qüestió prejudicial a aquest efecte. Aquest

\footnotetext{
${ }^{62}$ Sentència del TJCE de 5 d'abril de 1979, Ratti, as. C-148/78, Rep. 1979, p.1629.

63 Sentència del TJCE de 15 de juliol de 1964, Costa c. Enel, as. C-6/64, Rep. 1964, p.1141. En aquesta Sentència el TJCE disposava el següent: "el Tratado CEE ha instituido un ordenamiento jurídico propio integrado en el sistema jurídico de los Estados miembros a partir de su entrada en vigor y que se impone a sus órganos jurisdiccionales".

${ }^{64}$ Sentència del TJCE de 5 de febrer de 1963, Van Gend en Loos, as. C-26/62, Rep. 1963, p.3. En ella es conclou que: "la Comunidad constituye un nuevo ordenamiento jurídico [...] cuyos sujetos son, no sólo los Estados miembros, sino también sus nacionales; que, en consecuencia, el Derecho comunitario, autónomo respecto a la legislación de los Estados miembros, al igual que crea obligaciones a cargo de los particulares, está también destinado a generar derechos [...] que esos derechos nacen, no sólo cuando el Tratado los atribuye de modo explícito, sino también en razón de obligaciones que el Tratado impone de manera perfectamente definida tanto a los particulares como a los Estados miembros y a las instituciones comunitarias".

${ }^{65}$ Sentència del TJCE de 9 de març de 1978, Simmenthal, as. C-106/77, Rep. 1978, p.629. En aquesta Sentència el TJCE disposa que: "el juez nacional encargado de aplicar, en el marco de su competencia, las disposiciones del derecho comunitario, tiene la obligación de asegurar el pleno efecto de estas normas dejando inaplicada, si es preciso, y por su propia autoridad, cualquier disposición contraria de
} 
deure no es predica únicament dels jutges nacionals, sinó també de les Administracions Públiques nacionals ${ }^{66}$.

Per tant, si cap de les disposicions de la Directiva Marc tingués efecte directe per reunir els requisits identificats per la jurisprudència comunitària, la normativa nacional que la contravingués esdevindria inaplicable. Aquesta inaplicabilitat de la normativa nacional contrària a la Directiva podria pretendre's tant davant dels jutges nacionals com davant de les pròpies Administracions Públiques. Això succeiria amb independència del rang de la normativa interna, fins i tot en els supòsits en què aquesta normativa tingués rang de 11 ei ${ }^{67}$.

Aquest efecte directe de les Directives comunitàries ha estat reconegut per jurisprudència consolidada del $\mathrm{TJCE}^{68}$. Efectivament, si els particulars a qui una

la legislación nacional, incluso posterior, sin que sea necesario solicitar o esperar la eliminación previa por vía legislativa o por cualquier otro procedimiento constitucional'.

${ }^{66}$ Sentència del TJCE de 22 de juny de 1989, Fratelli Costanzo, as. C-103/88, Rep. 1989, p.1839. En aquesta Sentència s'estén la invocabilitat de les Directives i l'obligació d'inaplicar les normes nacionals contràries a aquesta a les Administracions Públiques nacionals:

\begin{abstract}
"30 It is important to note that the reason for which an individual may, in the circumstances described above, rely on the provisions of a directive in proceedings before the national courts is that the obligations arising under those provisions are binding upon all the authorities of the Member States.
\end{abstract}

31 It would, moreover, be contradictory to rule that an individual may rely upon the provisions of a directive which fulfil the conditions defined above in proceedings before the national courts seeking an order against the administrative authorities, and yet to hold that those authorities are under no obligation to apply the provisions of the directive and refrain from applying provisions of national law which conflict with them. It follows that when the conditions under which the Court has held that individuals may rely on the provisions of a directive before the national courts are met, all organs of the administration, including decentralized authorities such as municipalities, are obliged to apply those provisions.

32 With specific regard to Article 29(5) of Directive 71/305, it is apparent from the discussion of the first question that it is unconditional and sufficiently precise to be relied upon by an individual against the State. An individual may therefore plead that provision before the national courts and, as is clear from the foregoing, all organs of the administration, including decentralized authorities such as municipalities, are obliged to apply it.

33 The answer to the fourth question must therefore be that administrative authorities, including municipal authorities, are under the same obligation as a national court to apply the provisions of Article 29(5) of Council Directive 71/305/EEC and to refrain from applying provisions of national law which conflict with them".

67 BLÁZQUEZ ALONSO, N., NAVARRO MANICH, J. A., "La Directiva de Servicios y los establecimientos comerciales: el escenario del día después de la transposición”, Diario La Ley, núm. 7347 , p. 5 ss.

68 La Sentència paradigmàtica sobre aquesta qüestió és la de 4 de desembre de 1974, Van Duyn, as. C41/74, Rep. 1974, p.1337, en la que el TJCE disposava que: "sería incompatible con el efecto obligatorio 
Directiva comunitària reconeix un dret no poguessin invocar-lo davant dels poders públics i les jurisdiccions nacionals, minvaria l'efecte útil de la Directiva i la seguretat jurídica dels interessats ${ }^{69}$.

L'efecte directe de las Directives comunitàries requerirà, a més de la finalització del termini de transposició i d'una inexistent o deficient transposició de la Directiva, el compliment dels requisits disposats en la jurisprudència del TJCE. Aquests requisits han estat objecte d'una certa evolució jurisprudencial. En un primer moment, el TJCE exigia que la norma o el precepte de la Directiva que s'invoqués havia de ser, per la seva pròpia naturalesa, clara, precisa, i no havia de deixar marge d'apreciació discrecional ${ }^{70}$.

Tal i com ensenya la millor doctrina comunitarista ${ }^{71}$, la jurisprudència del TJCE va anar abandonant l'exigència de claredat. D'aquesta manera, aquest requisit es va anar concretant en l'exigència de que les disposicions d'una Directiva apareguin, des del punt de vista del seu contingut, com incondicionals i suficientment precises $^{72}$.

En conseqüència, la qüestió que haurà de ser analitzada és si el la Directiva Marc reconeix algun dret als particulars que sigui, des d'un punt de vista del seu contingut, incondicional i suficientment precís a la llum de la jurisprudència del TJCE.

A títol d'exemple, podem centrar-nos en la incorporació a la Directiva Marc del concepte de subproducte. Segons ha quedat exposat anteriorment, els subproductes no poden ser considerats com a residus $i$, per tant, no els resulta d'aplicació el seu règim d'intervenció i control administratiu. Aquest fet pot ser molt rellevant per als operadors. Efectivament, si una substància o objecte és un subproducte, segons allò disposat a l'article 5.1 de la Directiva Marc, es veuria exempt del compliment de les obligacions

que el artículo 189 reconoce a la directiva excluir, en principio, que la obligación que impone pueda ser invocada por las personas afectadas; que, particularmente, en el caso en el que las autoridades comunitarias hayan, por directiva, obligado a los Estados miembros a adoptar un comportamiento determinado, el efecto útil de tal acto se vería debilitado si los justificables no pudieran valerse en justicia de él y las jurisdicciones nacionales no pudieran tomarlo en consideración en tanto que elemento de Derecho comunitario [...] dado que se trata de una obligación para los Estados miembros [...] la seguridad jurídica de los interesados exige que esta obligación pueda ser invocada por ellos".

${ }^{69}$ El TJCE assenyala en la seva Sentència de 6 d'octubre de 1970, Franz Grad, as. C-9/70, Rep. 1970, p.825: "el efecto útil [...] se debilitaría si a los nacionales del Estado de que se trate se les privara de la posibilidad de invocarlo ante los órganos jurisdiccionales".

${ }^{70}$ Sentència del TJCE de 4 de desembre de 1974, Van Duyn, as. C-41/74, Rep. 1974, p.1337.

${ }^{71}$ RUIZ-JARABO COLOMER, El Juez nacional... cit., pp. 137-138.

${ }^{72}$ Sentència del TJCE de 19 de gener de 1982, Becker, as. C-8/81, Rep. 1982, p.53. 
relatives als residus, així com de l'aplicació del règim sancionador en matèria de residus.

En conseqüència, pot plantejar-se la hipòtesi de que, transcorregut el termini de transposició, la legislació i autoritats nacionals imposessin el règim d'intervenció i control en matèria de residus als subproductes. Podria, fins i tot, plantejar-se la possibilitat de que s'imposés una sanció a un operador per incomplir amb aquelles obligacions sobre residus en referència a una substància o objecte considerat subproducte per la Directiva Marc.

Doncs bé, davant d'aquesta situació, l'operador podria tractar d'invocar la Directiva Marc, a fi de que les autoritats nacionals inapliquessin la normativa nacional contrària a la norma comunitària, $\mathrm{i}$ apliquessin el règim jurídic del subproducte establert a la Directiva. Com s'ha assenyalat, aquesta pretensió podria esgrimir-se tant davant dels jutges nacionals com de les Administracions Públiques, tots ells vinculats pels principis de primacia i d'efecte directe del Dret comunitari.

Aquesta pretensió de l'operador només podria prosperar si les disposicions de la Directiva Marc sobre subproductes fossin incondicionals i suficientment precises. Cal assenyalar que aquest extrem, en aquest cas, es tractaria d'un punt qüestionable. Segons la pròpia literalitat de 1'article 5.1 de la Directiva Marc, no sembla que el precepte sigui suficientment incondicional quan disposa que una substància o objecte que reuneixi determinats requisits "puede ser considerada como subproducto". Amb aquesta fórmula, la Directiva Marc sembla estar atorgant un marge de discrecionalitat als Estats membres per definir què s'ha d'entendre per subproducte, que no s'ajustaria a l'exigència d'incondicionalitat i suficient precisió. Es tractarà, doncs, d'un supòsit discutible pel que fa a l'efecte directe vertical de l'article 5.1 de la Directiva Marc, que hauria de ser dilucidat per la jurisprudència.

Si aquest precepte relatiu als subproductes manqués d'efecte directe vertical per no considerar-se que compleix amb els requisits de ser suficientment precís i incondicional, els drets no podrien invocar-se directament davant les autoritats nacionals. Sense perjudici d'això, sí podria resultar d'aplicació el principi de responsabilitat de l'Estat pels danys causats als particulars per violacions del Dret comunitari ${ }^{73}$. Segons aquest

\footnotetext{
${ }^{73}$ Sentència del TJCE de 19 de novembre de 1991, Francovich, as. C-6/90 i C-9/90, Rep. 1991, p.I-5357.
} 
principi, els Estats membres són responsables de l'adequada transposició de la Directiva Marc, motiu pel qual, si la seva inadequada transposició genera perjudicis als particulars, aquests tindran el dret de ser reparats en els danys causats. Aquest supòsit requeriria que la transposició de la Directiva Marc fos deficient, i que aquestes deficiències fossin les que haguessin generat perjudicis als particulars.

\section{Efecte directe vertical "d'exclusió" de la Directiva Marc: paràmetre d'aplicació de les normes nacionals}

La jurisprudència del TJCE ha anat identificant una nova funció de l'efecte directe vertical de les Directives comunitàries, respecte de supòsits en que en aquestes no concorren les condicions per convertir-se en fonts de drets per als particulars, segons s'ha analitzat en l'apartat anterior.

En els casos de reconeixement de drets, es podria parlar d'un efecte directe de "substitució", donat que s'inaplica una norma nacional per aplicar el dret reconegut per la corresponent Directiva. Així, es produeix la substitució d'una norma per una altra.

En canvi, hi han supòsits en que la normativa nacional pot contradir una Directiva, però que no es reconegui un dret concret a favor d'un particular, o bé que no es donin els requisits exigits per la jurisprudència del TJCE per poder invocar aquell dret. En aquests casos podrà parlar-se d'un efecte directe "d'exclusió", quan la norma nacional hagi excedit del marge de discrecionalitat establert per la Directiva ${ }^{74}$.

Efectivament, tal i com s'infereix de l'article 288 del Tractat de funcionament de la Unió Europea, les Directives determinaran uns objectius i els Estats membres els assoliran a través dels mitjans i vies que considerin oportuns. En aquesta operació, com a norma general, els Estats membres disposaran d'un cert marge discrecional. Una excepció a aquesta discrecionalitat és el reconeixement de drets als particulars de manera precisa i incondicional, tal y com ha estat analitzat.

Aquest marge de discrecionalitat que la Directiva pot conferir als Estats membres per a la seva transposició pot tenir diverses manifestacions. Per exemple, la Directiva pot oferir diverses possibilitats entre les quals el legislador estatal n'haurà de triar una. Un

\footnotetext{
${ }^{74}$ MARTÍNEZ CAPDEVILA, C., "Otra virtualidad de las Directivas: su efecto directo de exclusión", Gaceta Jurídica de la Unión Europea y de la Competencia, núm. 244, juliol-agost 2006, pp. 3-5.
} 
altre exemple pot ser la imposició a l'Estat membre de regular una determinada matèria tot respectant uns límits o unes disposicions específiques del seu règim jurídic.

En una primera aproximació, les possibles disfuncions entre els límits del marge de discrecionalitat establerts en la Directiva i la normativa nacional de transposició hauria de solucionar-se segons el principi d'interpretació conforme, dissenyat per la jurisprudència del $\mathrm{TJCE}^{75}$. La normativa nacional ha d'interpretar-se de conformitat amb la Directiva i els seus paràmetres. Aquesta tècnica permet solucionar els dubtes o confusions que puguin sorgir d'una interpretació que no acabi d'ajustar-se als postulats de la Directiva.

L'evolució del principi d'interpretació conforme es materialitza en l'efecte directe "d'exclusió" quan la contradicció consisteix en la superació dels esmentats marges de discrecionalitat de la Directiva. Una interpretació conforme de la normativa nacional amb la Directiva no resultaria suficient per solucionar aquesta contradicció, tota vegada que pot no caber una interpretació conforme.

D'aquesta manera, encara que la Directiva no reconegui un dret a un particular en els termes de l'efecte directe de "substitució", podrà fiscalitzar-se la normativa de transposició de la Directiva en virtut de l'efecte directe "d'exclusió". Aquest efecte directe "d'exclusió" també resultarà aplicable respecte de l'actuació dels poders públics en els àmbits en què resulti d'aplicació la Directiva, quan no existeixi normativa de transposició $^{76}$.

\footnotetext{
${ }^{75}$ Sentència del TJCE de 13 de novembre de 1990, Marleasing, as. C-106/89, Rep. 1990, p.I-4135.

76 La Sentència del TJCE de 7 de setembre de 2004, Landelijke Vereniging tot Behoud van de Waddenzee, as. C-127/02, Rec.2004, p.I-7405, aplica en un cas d'absència de normativa de transposició l'efecte directe "d'exclusió":
}

“66 Por lo que atañe al derecho de un particular a invocar una directiva y a la facultad del
juez nacional para tomarla en consideración, sería incompatible con el efecto imperativo
que el artículo 249 CE reconoce a la directiva excluir, en principio, que los interesados
puedan invocar la obligación que ésta impone. En particular, en los casos en los que, a
través de una directiva, las autoridades comunitarias hayan obligado a los Estados
miembros a adoptar un comportamiento determinado, el efecto útil de tal acto quedaría
debilitado si se impidiera al justiciable invocarlo ante los tribunales y si los órganos
jurisdiccionales nacionales no pudieran tomarlo en consideración, como elemento del
Derecho comunitario, para verificar si, dentro de los límites de la facultad de que dispone
en cuanto a la forma y los medios de ejecutar la directiva, el legislador nacional ha
respetado los límites del margen de apreciación trazado por la directiva (véase la
sentencia Kraaijeveld y otros, antes citada, apartado 56). Lo mismo sucede cuando, en
caso de que no se haya adaptado el Derecho interno a la disposición pertinente de la
directiva en cuestión, se trata de averiguar si la autoridad nacional que ha adoptado el 
Per tant, els principis de primacia i d'efecte directe del Dret comunitari permetran que els jutges nacionals inapliquin aquella normativa de transposició que excedeixi dels marges discrecionals establerts per una Directiva ${ }^{77}$, així com, davant l'absència de normativa de transposició, apliqui els límits al marge de discrecionalitat que estableixi la Directiva.

Aquestes mateixes facultats estan reconegudes a les pròpies Administracions Públiques $^{78}$. Aquest fet resulta especialment d'interès, si tenim en compte que, davant una absència de normativa de transposició, les Administracions Públiques podrien aplicar els límits a la discrecionalitat dels Estats membres establerts a la Directiva Marc als casos concrets, en virtut de l'efecte directe "d'exclusió".

\title{
4. Efecte directe vertical de la Directiva Marc en "relacions triangulars"
}

L'efecte directe d'una Directiva comunitària únicament pot ser vertical, és a dir, les Directives únicament poden invocar-se en les relacions respecte dels poders públics, i no entre particulars ${ }^{79}$.

La jurisprudència del TJCE ha exclòs l'efecte directe horitzontal de les Directives, de tal manera que un particular pogués invocar i fer valer davant d'un altre particular una Directiva que no hagi estat transposada, o hagi estat transposada de manera

\begin{abstract}
acto impugnado ha respetado los limites del margen de apreciación trazado por dicha disposición. [...]

70 En consecuencia, procede responder a la quinta cuestión que un órgano jurisdiccional nacional, cuando debe verificar la legalidad de una autorización concedida para un plan o proyecto, en el sentido del artículo 6, apartado 3, de la Directiva sobre los hábitats, puede controlar si se han respetado los límites del margen de apreciación de las autoridades nacionales competentes fijados por esta disposición, incluso aunque el ordenamiento jurídico del Estado miembro afectado no haya sido adaptado a ésta pese a la expiración del plazo fijado al efecto."
\end{abstract}

${ }^{77}$ La Sentència TJCE de 9 de març de 1978, Simmenthal, as. C-106/77, Rep. 1978, p.629, disposava que les normes d'aplicabilidtat directa del Dret comunitari han de ser plena i uniformement aplicades en tots els Estats membres a partir de la seva entrada en vigor i durant tot el seu període de validesa. En coherència amb l'anterior, va afegir que el principi de primacia del Dret comunitari té com efecte la inaplicació de ple dret de qualsevol disposició de la legislació nacional contrària a les normes de Dret comunitari directament aplicables. Per fer efectiu l'anterior, aquesta Sentència reconeix al jutge nacional la facultat de fer tot el necessari per remoure les disposicions legislatives nacionals que poguessin constituir un obstacle, fins $\mathrm{i}$ tot temporal, a la plena eficàcia de les normes comunitàries.

${ }^{78}$ Sentència del TJCE de 22 de juny de 1989, Fratelli Costanzo, as. C-103/88, Rep. 1989, p.1839.

${ }^{79}$ Sentència del TJCE de 26 de febrer de 1986, Marshall, as. C-152/84, Rep. 1986, p. 723. 
inadequada ${ }^{80}$. En virtut del principi de seguretat jurídica, respecte d'un altre particular únicament podrà invocar-se la normativa nacional de transposició de la Directiva. L'única manera en què una Directiva tindrà efectes en relacions entre privats serà a través del principi de interpretació conforme ${ }^{81}$, el qual està subjecte al propi límit de que una interpretació conforme sigui possible, o que existeixi una norma nacional respecte de la qual es pugui aplicar aquesta tècnica interpretativa.

E1 TJCE ha dictat diverses sentències en matèria de medi ambient en les quals es tracta d'un supòsit en què la invocació d'una Directiva afectarà a un altre particular, però que es diferencia de l'efecte directe horitzontal de les Directives: la invocabilitat de Directives per part de particulars en les relacions triangulars ${ }^{82}$.

Aquestes relacions triangulars es caracteritzen pel fet de que l'aplicació directa de la Directiva a favor d'un particular suposa el compliment d'una obligació imposada als Estats membres en virtut d'aquella, però aquest compliment té repercussions per a un altre particular ${ }^{83}$. La Directiva imposa a l'Estat membre el compliment d'una obligació, aquest compliment beneficia a un particular però, a la vegada, perjudica a un altre.

Aquests supòsits guarden una certa semblança amb els de l'efecte directe horitzontal de les Directives, tota vegada que hi han dos particulars, un que exigeix el compliment de la Directiva, i un altre que es veu afectat negativament per aquest compliment. Però les relacions triangulars es diferencien de manera substancial amb els casos d'efecte directe horitzontal en el fet que intervé una autoritat pública nacional.

L'efecte directe en les relacions triangulars és vertical, donat que es tracta de fer complir una obligació imposada a l'Estat membre per la Directiva. En conseqüència, no pot assimilar-se als casos d'efecte directe horitzontal, que no estan permesos per la jurisprudència del TJCE.

\footnotetext{
${ }^{80}$ Sentència del TJCE de 14 de juliol de 1994, Faccini Dori, as. C-91/92, Rep. 1994, p.I-3325.

${ }^{81}$ Sentència del TJCE de 13 de novembre de 1990, Marleasing, as. C-106/89, Rep. 1990, p.I-4135.

82 JORDANO FRAGA, J., "Efecto directo horizontal de determinadas Directivas ambientales: la consagración jurisprudencial de la invocabilidad por particulares de las Directivas en relaciones triangulares", Revista Española de Derecho Administrativo, núm. 124, 2004, pp. 645-659.

83 DE COCK, K., "Case Reports: Case C-201/02 Wells v. Secretary of State for Transport, Local Government and the Regions", European Environmental Law Review, núm. 5, maig 2004, p. 136.
} 
No obstant això, davant l'absència de normativa nacional de transposició, el TJCE es planteja quins són els límits d'aquest efecte directe vertical en relacions triangulars ${ }^{84}$.

E1 TJCE conclou que el límit d'aquest efecte directe consistirà en que l'obligació que ha de complir l'Estat membre, en virtut de la Directiva, no estigui directament vinculada amb l'execució d'una obligació que correspon a un altre particular en virtut de la mateixa Directiva. A aquests efectes, dues obligacions estan directament vinculades quan una obligació no es pot complir sense l'execució de l'altre, i que ambdues es prescriguin en la mateixa Directiva ${ }^{85}$. D'aquesta manera, si el compliment d'aquella obligació per part de l'Estat suposa que un particular haurà d'executar una altra obligació imposada per aquella Directiva, no serà admissible l'efecte directe vertical.

En canvi, si el compliment de l'obligació imposada a l'Estat membre suposa unes meres repercussions negatives per a un particular, sí serà admissible l'efecte directe vertical en relacions triangulars. Un exemple de repercussions negatives sí admissibles per a que pugui donar-se aquest supòsit, podria ser la suspensió d'un procediment d'autorització d'un projecte, a fi de l'autoritat pública compleixi amb determinades obligacions imposades per una Directiva, com seria dur a terme una avaluació d'impacte ambiental.

${ }^{84}$ Sentència del TJCE de 7 de gener de 2004, Wells, as. C-201/02, Rep. 2004, p.I-723. En aquesta sentència s'assenyala el següent:

"56 A este respecto, es preciso señalar que el principio de seguridad jurídica se opone a que las directivas puedan crear obligaciones a cargo de los particulares. Respecto a estos últimos, las disposiciones de una directiva sólo pueden crear derechos (véase la sentencia de 26 de febrero de 1986, Marshall, 152/84, Rec. p. 723, apartado 48). Por consiguiente, un particular no puede invocar una directiva contra un Estado miembro cuando se trata de una obligación estatal que está directamente relacionada con la ejecución de otra obligación que incumbe a un tercero, en virtud de esta directiva (véanse, en este sentido, las sentencias de 22 de febrero de 1990, Busseni, C-221/88, Rec. p. I-495, apartados 23 a 26, y de 4 de diciembre de 1997, Daihatsu Deutschland, C-97/96, Rec. p. I-6843, apartados 24 y 26).

57 En cambio, las meras repercusiones negativas sobre los derechos de terceros, incluso si pueden preverse con seguridad, no justifican que se niegue a un particular la posibilidad de invocar las disposiciones de una directiva contra el Estado miembro de que se trate (véanse en este sentido, en particular, las sentencias de 22 de junio de 1989, Fratelli Costanzo, 103/88, Rec. p. 1839, apartados 28 a 33; WWF y otros, antes citada, apartados 69 y 71; de 30 de abril de 1996, CIA Security International, C-194/94, Rec. p. I-2201, apartados 40 a 55: de 12 de noviembre de 1996. Smith \& Nephew y Primecrown, C-201/94, Rec. p. I-5819, apartados 33 a 39, y de 26 de septiembre de 2000, Unilever, C-443/98, Rec. p. I-7535, apartados 45 a 52)."

85 DE COCK, K., "Case Reports: Case C-201/02 Wells v. Secretary of State for Transport, Local Government and the Regions", en European Environmental Law Review, núm. 5, maig 2004, p. 136. 
Resulta també d'interès assenyalar que en aquests casos de relacions triangulars en matèria de medi ambient, els particulars que invoquen l'efecte directe de la Directiva no han de provar que aquesta norma els atorgui un dret individual. Resulta suficient acreditar un interès en l'aplicació de les prescripcions de la Directiva ${ }^{86}$.

La inadequada transposició de la Directiva Marc podria plantejar algunes relacions triangulars que podrien ser rellevants en quant a un possible efecte directe vertical de la Directiva.

A títol d'exemple, podem citar el supòsit hipotètic de que la legislació interna no hagués adaptat adequadament el règim d'autoritzacions i registres en matèria de residus $\mathrm{i}$, concretament, la nova regulació no imposés el contingut mínim de les autoritzacions establert per l'article 23.1 de la Directiva $\operatorname{Marc}^{87}$.

En aquest supòsit podria plantejar-se la possibilitat de què un tercer (e.g. una associació ecologista) impugnés l'autorització d'un abocador per no regular les mesures de seguretat i precaució que haurien de prendre's i el mètode que hauria d'utilitzar-se per a cada tipus d'operació.

En aquest supòsit, el tercer podria tractar d'invocar la Directiva Marc en el marc de la impugnació administrativa o judicial de l'autorització a fi de que les autoritats nacionals inapliquessin la normativa nacional contrària a la Directiva Marc, $\mathrm{i}$ apliquessin el règim jurídic de l'expedició d'autoritzacions imposat a la Directiva, en virtut dels principis de primacia i d'efecte directe del Dret comunitari.

En definitiva, en aquest cas, si prosperés el recurs interposat pel tercer, l'autorització de l'abocador seria anul-lada per aplicació de l'efecte directe vertical en relacions triangulars, i això amb independència de les repercussions negatives per podria suposar per el titular de l'abocador. Efectivament, aquestes repercussions negatives no consistiran en una obligació imposada per la Directiva directament vinculada amb l'obligació que ha de complir l'Estat membre.

\footnotetext{
${ }^{86}$ Op. cit., p. 137.

${ }^{87}$ Recordem que aquest article preveu que l'autorització haurà de contenir, com a mínim: (i) els tipus i quantitats de residus que poden tractar-se; (ii) per a cada tipus d'operació autoritzada, els requisits tècnics i de qualsevol altre tipus aplicables al lloc corresponent; (iii) les mesures de seguretat i precaució que hauran de prendre's; (iv) el mètode que s'utilitzarà per a cada tipus d'operació; (v) les operacions de supervisió i de control que puguin resultar necessàries; i (vi) les disposicions relatives al tancament i al manteniment posterior que puguin ser necessàries.
} 


\section{CONCLUSIONS}

La nova Directiva Marc de residus ha introduït nous conceptes, revisant-ne d'altres, i aborda les condicions marc de la producció i gestió de residus.

D’acord amb l'anterior, cal destacar, entre els aspectes més significatius, els següents:

(i) La Directiva ha incorporat la doctrina emanada pel TJCE dels últims anys relativa al concepte de subproducte i matèria primera secundària, així com de valorització i eliminació.

(ii) S'ha establert una jerarquia de cinc nivells per a les opcions de gestió de residus, que es configura com a ordre de prioritats en la legislació i la política sobre prevenció i gestió de residus.

(iii) S'incorpora el concepte de subproducte, entès com aquelles substàncies o objectes que, fins i tot no essent la finalitat primària d'un procés de producció, compleixen determinades condicions, i podrien excloure's de la definició de residu. També s'incorpora el concepte de fi de la condició de residu, tot establint unes condicions generals que s'hauran de complir per poder determinar que en un punt determinat de la cadena de tractament, una substància o objecte perd la qualificació jurídica de residu i ja no li és d'aplicació la legislació de residus.

(iv) En relació amb la valorització, és necessari que l'operació tingui una funció útil, substituint materials que d'una altra manera s'haurien utilitzat per complir la mateixa funció. En aquest context, les operacions d'incineració de residus sòlids urbans només tindran consideració de valorització quan assoleixin un determinat paràmetre d'eficiència energètica.

(v) La Directiva té una clara vocació de transformar la Unió Europea en una "societat del reciclat", i és per aquest motiu que s'han fixat objectius de reutilització i reciclatge per a determinats residus a arribar abans de 2020 i s'estableix l'obligació de tots els Estats membres de dur a terme la recollida selectiva dels residus i, com a mínim, del paper, metalls, plàstic i vidre per a l'any 2015. 
(vi) Els Estats membres hauran d'aprovar plans de prevenció de residus, de tal manera que s'aconsegueixi trencar el vincle entre el creixement econòmic i els impactes mediambientals associats a la generació de residus.

Sense perjudici de l'anterior, la Directiva ha estat objecte de crítica per representants europeus i organitzacions ecologistes que la consideren "massa feble" en comparació amb els problemes derivats de l'increment en la generació de residus i el canvi climàtic.

Pel que fa a les principals línies d'actuació que contempla el Grup de Treball del Ministeri que treballa en la transposició, podem destacar les següents:

(i) Amb plena intenció de delimitar la responsabilitat en la gestió dels residus, es preveu classificar els residus urbans en domèstics, comercials i industrials.

(ii) Atenent als objectius marcats per la Directiva en relació amb la recollida separada i la reutilització i reciclat de residus, es preveuen diferents modalitats, entre les quals es podria optar per a la seva consecució.

(iii) Als efectes d'impulsar la recollida separada de biorresidus, s'ha previst incloure uns objectius proporcionals durant una sèrie d'anys per arribar a assolir la recollida selectiva d'almenys el 50\% dels biorresidus.

(iv) S'ha procedit a delimitar les Administracions competents en les concessions d'autoritzacions, així com per gestionar els preceptius registres.

(v) Es proposa substituir l'actual autorització als productors de residus perillosos per una comunicació a l'òrgan ambiental competent de la Comunitat Autònoma.

De tota manera, als efectes de poder valorar les consideracions efectuades pel Ministeri hem de tenir present que en l'ordenació jurídica espanyola la distribució de competències entre 1'Administració Central i les Comunitats Autònomes en matèria de residus comporta que existeixi una regulació molt heterogènia.

A la pràctica això es tradueix en la coexistència de procediments i requeriments diferents per a la mateixa activitat aplicables en funció del punt geogràfic en el qual la mateixa es desenvolupa. Això pot generar un problema a l'hora de traslladar la norma per les diferents formes de procedir que tingui cada òrgan autonòmic.

No obstant això, fora bo aprofitar l'oportunitat que ofereix la transposició de la Directiva Marc per tendir a l'harmonització dels diferents règims autonòmics. 


\section{BIBLIOGRAFIA CONSULTADA}

ABELLÁN HONRUBIA, V., VILA COSTA, B. (dirs.) i OLESTI RAYO, A. (coord.), Lecciones de Derecho Comunitario Europeo, $4^{\mathrm{a}}$ edició, Ariel, Barcelona, 2005.

ALENZA GARCÍA, J.F., "Reflexiones críticas sobre la nueva Ley de residuos", Medio Ambiente \& Derecho: revista electrónica de Derecho ambiental, núm. 3, 1999.

BLÁZQUEZ ALONSO, N., NAVARRO MANICH, J. A., "La Directiva de Servicios y los establecimientos comerciales: el escenario del día después de la transposición", diario La Ley, núm. 7347, pp. 1-8.

CAMPINS ERITJA, M., BORRÀS PENTINAT, S., PIGRAU SOLÉ, A., "La adopción de una perspectiva integrada en la política comunitaria ambiental: la Directiva 96/61/CE relativa a la prevención y control integrados de la contaminación", Vernet I Llobet, J. i Baucells i Lladós. J. (coords.), La prevención y control integrados de la contaminación, Marcial Pons, Madrid, 2004.

DE COCK, K., "Case Reports: Case C-201/02 Wells v. Secretary of State for Transport, Local Government and the Regions", European Environmental Law Review, núm. 5, maig 2004, pp. 132-139.

DE MIGUEL PERALES, C., Régimen jurídico español de suelos contaminados, Civitas, Pamplona, 2007.

FERNÁNDEZ RAMOS, S., "El marco jurídico comunitario en materia de residuos", Noticias de la Unión Europea, núm. 153, 1997, pp. 37-56.

JARIA I MANZANO, J., "Problemas competenciales fundamentales en materia de protección del medio ambiente", Revista Vasca de Administración Pública, núm. 73-I, 2005, pp. 117-134.

JIMÉNEZ PLAZA, C., La gestión de residuos en los municipios, $1^{\mathrm{a}}$ edició, Iustel, Madrid, 2006.

JORDANO FRAGA, J., "Efecto directo horizontal de determinadas Directivas ambientales: la consagración jurisprudencial de la invocabilidad por particulares de las Directivas en relaciones triangulares", Revista Española de Derecho Administrativo, núm. 124, 2004, pp. 645-659. 
MARTÍN MATEO, R., Tratado de Derecho Ambiental (II), Trivium, Madrid, 1992.

MARTÍNEZ CAPDEVILA, C., "Otra virtualidad de las Directivas: su efecto directo de exclusión”, Gaceta Jurídica de la Unión Europea y de la Competencia, núm. 244, juliol-agost 2006, pp. 3-16.

ORTEGA BERNARDO, J., La intervención pública en la gestión de los residuos industriales, Montecorvo, Madrid, 2002.

ORTEGA BERNARDO, J., Estado, Comunidades Autónomas y Corporaciones Locales ante la gestión de los residuos urbanos, Marcial Pons, Madrid, 2003.

PÉREZ RIVARÉS, J. A., VIGUER PONT, J., "La transposición de la Directiva Bolkestein en el ámbito de la ordenación comercial", Revista Española de Derecho Europeo, núm. 32, 2009, pp. 503-530.

POVEDA GÓMEZ, P., Envases y residuos de envases. Nueva legislación. Comentarios a la Ley 11/1997, de 24 de abril, Exlibris Ediciones, Madrid, 1997.

RUIZ-JARABO COLOMER, D., El Juez nacional como Juez Comunitario, Cuadernos de Estudio Europeo, Civitas, Madrid, 1993.

SANTAMARÍA ARINAS, J.M., Régimen jurídico de la producción y gestión de residuos, Monografías de la Revista Aranzadi de Derecho Ambiental, núm. 11, Madrid, 2007.

SERRANO LOZANO, R., El régimen jurídico de los residuos de envases, Dykinson, Madrid, 2007.

SERRANO PAREDES, O., "Aportaciones recientes de la jurisprudencia del TJCE en torno al concepto de residuo: los llamados 'indicios", Revista Aranzadi de Derecho Ambiental, núm. 6, 2004, pp. 125-137.

— "La Directiva 2006/12/CE, de 5 de abril, relativa a los residuos: algunas cuestiones controvertidas: los conceptos de residuo, valoración y eliminación", Revista Aranzadi de Derecho Ambiental, núm. 11, 2007, pp. 65-88.

- "Una distinción con importantes consecuencias jurídicas: residuo, subproducto y materia prima secundaria”, Revista de Derecho Urbanístico y Medio Ambiente, núm. 239, 2008, pp. 145-201. 
— "La plasmación de criterios jurisprudenciales en la Directiva 2008/98/CE, de 19 de noviembre, sobre los residuos", Revista Aranzadi de Derecho Ambiental, núm. 16, 2009, pp. 145-153.

— "La Nueva Directiva de Residuos: Principales Novedades", Ecosostenible, núm. 47, gener 2009, pp. 4-11. 